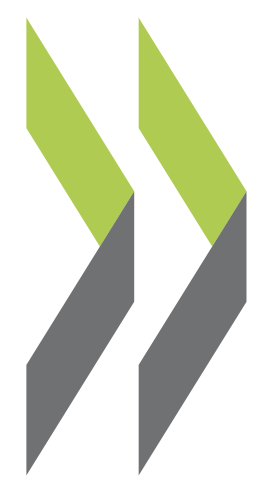

OECD Economics Department Working Papers No. 1499

Who are the beneficiaries of the structural funds and the cohesion fund and how does the cohesion Julia Bachtrögler, policy impact firm-level performance? 
Organisation de Coopération et de Développement Économiques

Organisation for Economic Co-operation and Development

30-Jul-2018

ECONOMICS DEPARTMENT

English - Or. English

WHO ARE THE BENEFICIARIES OF THE STRUCTURAL FUNDS AND THE COHESION FUND AND HOW DOES COHESION POLICY IMPACT FIRM-LEVEL PERFORMANCE?

ECONOMICS DEPARTMENT WORKING PAPERS No. 1499

By Julia Bachtrögler and Christoph Hammer

OECD Working Papers should not be reported as representing the official views of the OECD or of its member countries. The opinions expressed and arguments employed are those of the author(s).

Authorised for publication by Isabell Koske, Deputy Director, Country Studies Branch, Economics Department.

All Economics Department Working Papers are available at www.oecd.org/eco/workingpapers

JT03434821

This document, as well as any data and map included herein, are without prejudice to the status of or sovereignty over any territory, to the delimitation of international frontiers and boundaries and to the name of any territory, city or area. 
OECD Working Papers should not be reported as representing the official views of the OECD or of its member countries. The opinions expressed and arguments employed are those of the author(s).

Working Papers describe preliminary results or research in progress by the author(s) and are published to stimulate discussion on a broad range of issues on which the OECD works.

Comments on Working Papers are welcomed, and may be sent to OECD Economics Department, 2 rue André Pascal, 75775 Paris Cedex 16, France, or by e-mail to eco.contact@oecd.org.

All Economics Department Working Papers are available at www.oecd.org/eco/workingpapers.

This document and any map included herein are without prejudice to the status of or sovereignty over any territory, to the delimitation of international frontiers and boundaries and to the name of any territory, city or area.

The statistical data for Israel are supplied by and under the responsibility of the relevant Israeli authorities. The use of such data by the OECD is without prejudice to the status of the Golan Heights, East Jerusalem and Israeli settlements in the West Bank under the terms of international law.

On 3 May 2018, the OECD Council invited Lithuania to become a Member. At the time of publication the deposit of Lithuania's instrument of accession to the OECD Convention was pending and therefore Lithuania does not appear in the list of OECD Members and is not included in the OECD zone aggregates.

On 25 May 2018, the OECD Council invited Colombia to become a Member. At the time of publication the deposit of Colombia's instrument of accession to the OECD Convention was pending and therefore Colombia does not appear in the list of OECD Members and is not included in the OECD zone aggregates.

\section{(C) OECD (2018)}

You can copy, download or print OECD content for your own use, and you can include excerpts from OECD publications, databases and multimedia products in your own documents, presentations, blogs, websites and teaching materials, provided that suitable acknowledgment of OECD as source and copyright owner is given. All requests for commercial use and translation rights should be submitted to rights@oecd.org 
ECO/WKP(2018)47

\section{ABSTRACT/RÉSUMÉ}

\section{Who are the beneficiaries of the structural funds and the cohesion fund and how does the cohesion policy impact firm-level performance?}

This paper exploits a new database that is unique in its scale and scope containing detailed information on over two million projects carried out by one million firms that benefited from the European Regional Development Fund, the European Social Fund and the Cohesion Fund in 25 EU member countries during the multi-annual financial framework 2007-2013. This database is used to get a better understanding of the characteristics of the beneficiaries of European funds and to assess the impact of the European funds on the beneficiaries' performance in terms of employment growth, growth in fixed assets, and total factor productivity.

While the data reveals substantial heterogeneity of beneficiaries and projects across and within countries, in terms of the number of projects, their total values, the average firm size and other aspects, some patterns are identified. The majority of co-funding goes to manufacturing firms as well as public institutions. The Cohesion Fund co-finances larger projects, carried out by larger, more capital-intensive firms that typically conduct large-scale infrastructure projects. In contrast, the European Social Fund co-finances smaller projects related to human capital and initiatives on the labour market. In terms of volume, the European Regional and Development Fund has the largest budget in total and co-finances a large variety of projects. Using propensity score matching techniques, we find mixed effects of structural and cohesion funds on the performance of a sample of manufacturing firms in six European countries. On average, firms that receive financial assistance hire more workers and increase their capital stock more. However, there is little evidence of additional positive total factor productivity effects for the beneficiaries.

This Working Paper relates to the 2018 OECD Economic Survey of the European Union (http://www.oecd.org/eco/surveys/economic-survey-european-union-and-euro-area.htm) JEL Classification: C21, D22, E61, R11, R58

Keywords: Cohesion Policy, European Union, Propensity Score Matching, Treatment Effects, Firm-level data

$* * * * * * * * * *$

\section{Qui sont les bénéficiaires des fonds structurels et du Fonds de cohésion, et quel est l'impact de la politique de cohésion sur les résultats au niveau des entreprises ?}

Le présent document de travail a été élaboré à partir, d'une base de données unique en son genre en termes d'envergure et de portée, qui contient des informations détaillées sur plus de deux millions de projets réalisés par un million d'entreprises ayant bénéficié de programmes du Fonds européen de développement régional, du Fonds social européen et du Fonds de cohésion dans 25 pays membres de l'UE au titre du cadre financier pluriannuel 2007-2013. Cette base de données permet de mieux comprendre les spécificités des bénéficiaires des fonds européens et d'évaluer l'impact de ces fonds sur leurs performances en matière de progression de l'emploi, d'augmentation des immobilisations et de productivité totale des facteurs.

Si l'analyse de ces données fait ressortir la grande hétérogénéité des bénéficiaires et des projets entre les différents pays et à l'intérieur de ceux-ci, qu'il s'agisse du nombre de projets, de leur valeur totale, de la taille moyenne des entreprises et d'autres aspects, certaines caractéristiques peuvent toutefois être dégagées. La majorité des co-financements concerne les entreprises du secteur manufacturier et les institutions publiques. Le Fonds de cohésion cofinance de vastes projets, menés par de grandes entreprises à forte intensité capitalistique qui travaillent généralement sur des projets d'infrastructures à grande échelle. En revanche, le Fonds social européen cofinance de plus petits projets portant sur le capital humain et des initiatives sur le marché du travail. En volume, c'est le Fonds européen de développement régional qui possède le budget total le plus important, et il cofinance une large palette de projets. 
À l'aide de techniques d'appariement par score de propension, nous avons constaté les effets mitigés qu'ont eus les fonds structurels et de cohésion sur les performances d'un échantillon d'entreprises du secteur manufacturier dans six pays européens. En moyenne, les entreprises qui reçoivent une aide financière embauchent plus de travailleurs et augmentent davantage leur stock de capital. En revanche, il n'y a guère d'éléments indiquant des effets positifs supplémentaires, pour les bénéficiaires, quant à la productivité totale des facteurs.

Ce Document de travail se rapporte à l'Étude économique de l'OCDE de l'Union Européenne, 2018 (http://www.oecd.org/fr/eco/etudes/etude-economique-union-europeenne-et-zone-euro.htm) Classification JEL: C21, D22, E61, R11, R58

Mots clefs: politique de cohésion, Union Européenne, techniques d'appariement par score de propension, effets de traitement, données d'entreprise 


\section{TABLE OF CONTENTS}

\section{WHO ARE THE BENEFICIARIES OF THE STRUCTURAL FUNDS AND THE COHESION FUND AND HOW DOES COHESION POLICY IMPACT FIRM-LEVEL PERFORMANCE? …........................7}

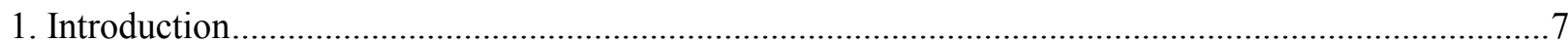

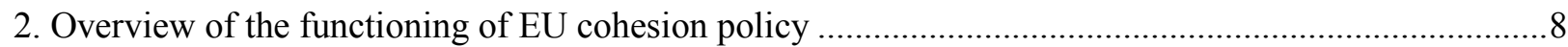

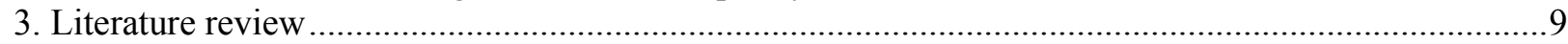

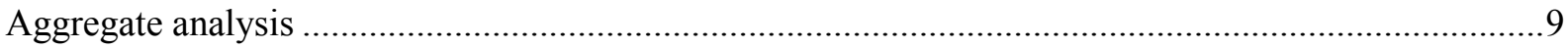

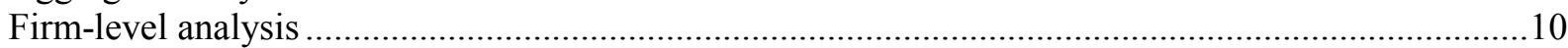

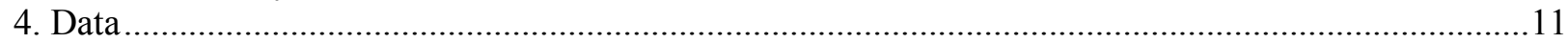

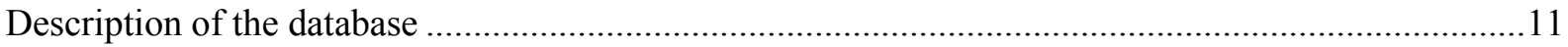

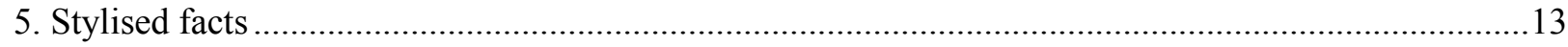

Stylised facts: Differences by EU member country or region............................................................14

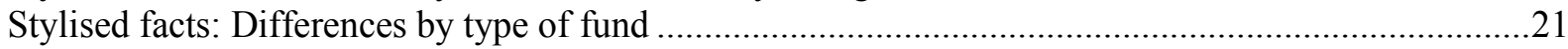

6. The impact of cohesion policy on actual beneficiaries' performance ...................................................22

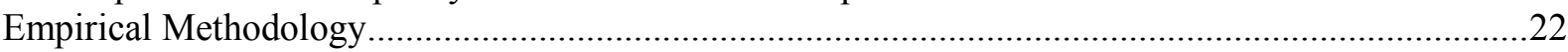

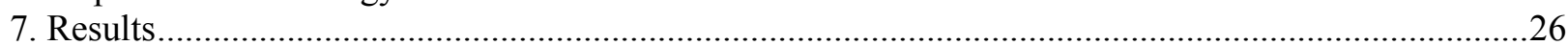

Results on firms' employment, operating revenue (per employee) and total factor productivity...........26

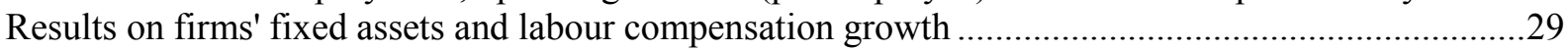

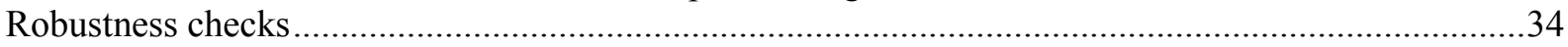

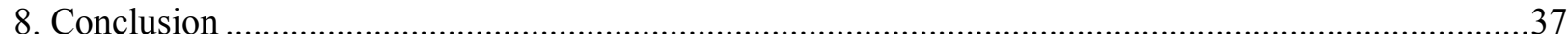

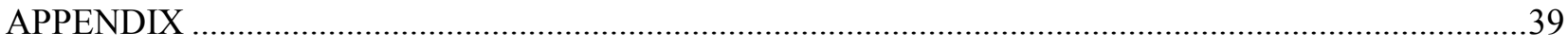

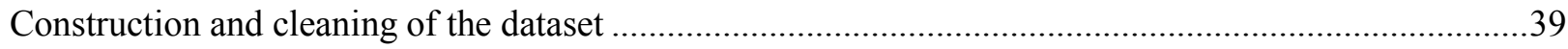

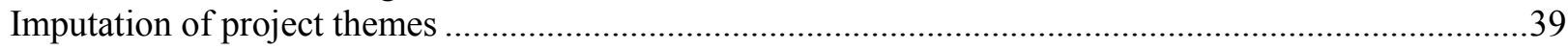

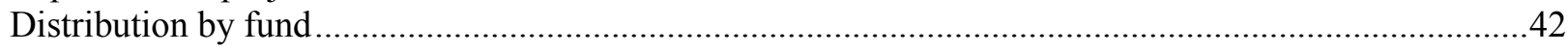

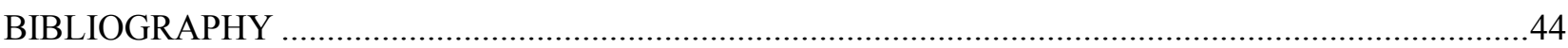

\section{Tables}

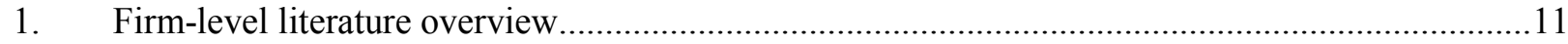

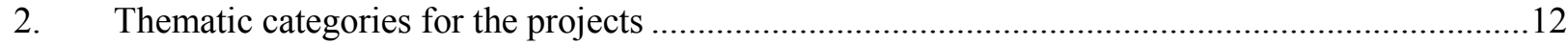

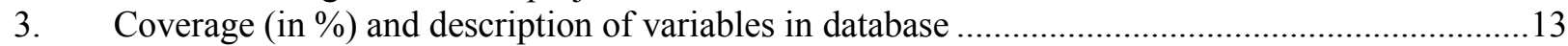

4. Country distribution: number of projects, firms and average firm size ........................................14

5. Beneficiaries: Average value added and operating revenue by country .....................................16

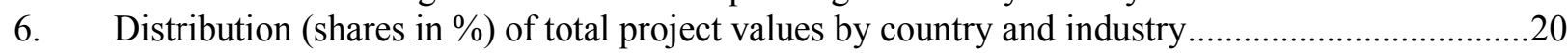

7. Distribution of total values of different type of funds across NACE industries ..........................21

8. Distribution of total values of different type of funds across themes ..........................................22

9. Comparison of structural funds beneficiaries and the control group ............................................24

10. T-test for the significance of mean differences across the outcome variables of structural funds

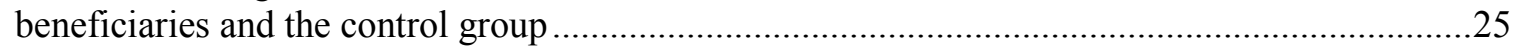

11. Average treatment effects on the treated (ATT) on a set of firm performance indicators and

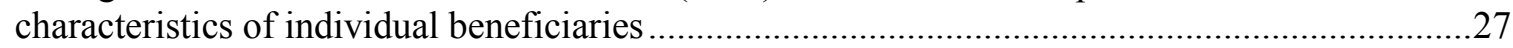

12. Average treatment effects on the treated (ATT) considering multiple projects per beneficiary - Per

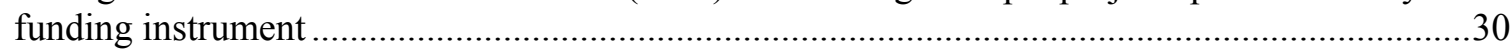

13. Average treatment effects on the treated (ATT) considering multiple projects per beneficiary - per

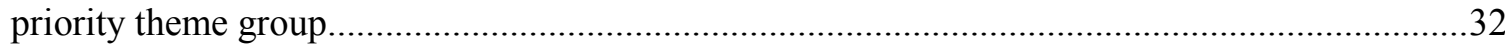


14. Robustness check: Average treatment effects on the treated (ATT) considering individual beneficiaries: Including the NACE Rev. 2-1 digit code. . .34

15. Robustness check: Average treatment effects on the treated (ATT) considering multiple projects per beneficiary but excluding the smallest projects

\section{Figures}

1. Total values relative to regional GDP .15

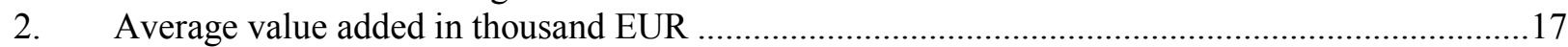

3. Distribution of total values by country and quintile of fixed assets ............................................18

4. Distribution of total values by country and quintile of capital-labour ratio ...................................18

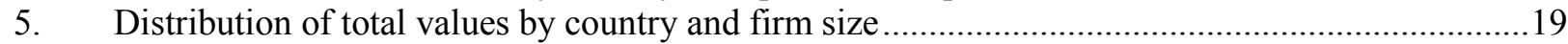

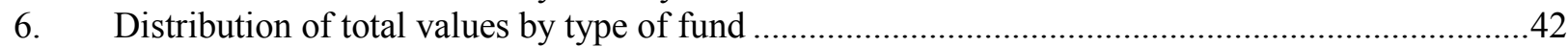

7. Distribution of firms' amount of total assets by type of fund ......................................................

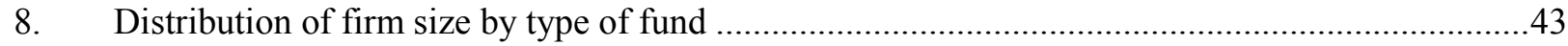

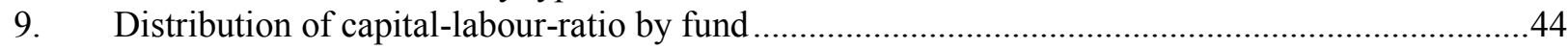


ECO/WKP(2018)47

\title{
WHO ARE THE BENEFICIARIES OF THE STRUCTURAL FUNDS AND THE COHESION FUND AND HOW DOES COHESION POLICY IMPACT FIRM-LEVEL PERFORMANCE?
}

\author{
By Julia Bachtrögler and Christoph Hammer ${ }^{1}$
}

\section{Introduction}

1. Cohesion policy is the largest redistributive policy in Europe. EUR 340 billion were transferred across European regions between 2007 and 2013. The main goals of the policy are to foster the catching-up process of lagging regions as well as cohesion in economic and social terms. In order to see if the policy achieves its goals, economists so far have mainly used rather aggregate data provided by the European Commission and the conclusions in the academic literature are mixed so far.

2. This paper presents a new database that is unique in its scale and scope. It is the first database that contains micro-level information on over two million single projects co-funded by the European structural and cohesion funds in $25 \mathrm{EU}$ member countries during the multi-annual financial framework (MFF) 2007-2013. ${ }^{2}$ It contains not only information about the project itself, its size, location, thematic category and co-financing structure but also data on the beneficiary firm or institution that carries out the project. The firm information is taken from Bureau van Dijk's ORBIS business database and is merged with the beneficiaries' data. Data on the beneficiary firms and institutions is collected from numerous national and regional sources that are published for the public by managing authorities since 2007 .

3. This database allows a more detailed analysis of EU cohesion policy by providing information on the recipients that carry out the projects. Thus, the present paper provides an overview of EU cohesion policy 2007-2013 with a focus on firm characteristics, an analysis that was not possible before at this level of aggregation.

4. There is large variation in terms of project values and the number of projects conducted across European countries and regions. On average and relative to their GDP, poorer regions receive higher cofunding than richer regions. Since regions and countries have distinct objectives and thematic priorities, the firms that apply for those projects in different regions are not alike in several aspects. They differ e.g. with respect to average firm size or their average productivity. While there is variation across countries among many dimensions (projects and firm characteristics), some patterns emerge. On average, and not conditional on other factors, the largest sums of co-funding are associated with firms that (i) have relatively many (fixed) assets, (ii) a high capital-labour ratio but (iii) are small or medium in size (less than 150 employees) and (iv) operate in the manufacturing sector or are public authorities. When investigating the funding structure of the three main co-financing instruments, we can see that the median project is largest (in terms of its total project value) when co-funded by the Cohesion Fund (CF) compared to the European Regional Development Fund (ERDF) and the European Social Fund (ESF). These differences emerge due to different aims of the funds, e.g., the Cohesion Fund mainly finances infrastructure projects. Distinct

\footnotetext{
${ }^{1}$ Corresponding author, Christoph Hammer, Vienna University of Economics and Business, Welthandelsplatz 1, 1020 Vienna, Austria. E-Mail: christoph.hammer@wu.ac.at. Julia Bachtrögler, Austrian Institute of Economic Research (WIFO), Arsenal Object 20, 1030 Vienna, Austria. E-mail: julia.bachtroegler@wifo.ac.at. We would like to thank Peter Gal and Francesco Gerotto from the OECD Economics Department for sharing the codes to compute total factor productivity and Aida Caldera Sanchez for constructive feedback and comments as well as the participants in the OECD brownbag seminar. Further, we want to thank Alexander Lembcke (Centre for Entrepreneurship, SMEs, Regions and Cities) and Peter Gal (Economics department) for constructive feedback.

${ }^{2}$ The respective region or member state additionally co-finances those projects. Some expenses are also borne by the receiving firm themselves.
} 
priorities are also reflected in differences across typical business characteristics of the respective beneficiaries.

5. We show how cohesion policy affects a subset of firms on a micro level. Based on Bachtrögler et al. (2017a), we estimate the effects of carrying out a co-funded project on a set of beneficiaries' firm performance indicators and characteristics. The analysis shows that manufacturing firms in Italy and Portugal, i.e. firms that receive co-funding from the ERDF, the ESF or the CF, create six to ten jobs more than they would have without receiving funds. Moreover, supported firms in all countries included in the subsample experience additional growth in fixed assets, revenue and their capital-labour-ratio. The effect on total factor productivity, measured as Solow residual, turns out to be significant for manufacturing firms located in Spain and Portugal. The distinction of projects co-funded by different funding instruments or corresponding to different priority themes allows us to draw further conclusions on the policy impact on firm performance.

6. The paper is organised as follows. Section 2 provides an overview of EU cohesion policy over 2007-2013 including its objectives and organisation. Section 3 summarises the evidence on the impact of cohesion policy, which so far has mostly relied on regional data or covered fewer countries or regions. We show how the new database can improve existing analyses as well as which new questions can be answered. Section 4 describes the database in more detail. Section 5 presents descriptive statistics on the distribution of projects or project values across project and beneficiary characteristics. Section 6 describes the methodology that is used in order to estimate firm-level treatment effects. Corresponding results, together with several robustness checks, are presented and discussed in Section 7. Finally Section 8 concludes.

\section{Overview of the functioning of EU cohesion policy}

7. EU cohesion policy aims at increasing regional economic and social cohesion across Europe. The funds that amounted to EUR 340 billion during the multi-annual financial framework (MFF) 2007$2013^{3}$, are allocated across regions to achieve the following objectives, i) Convergence, ii) Regional Competitiveness and Employment and ii) Territorial cooperation, formerly known as Objective 1, 2 and 3 respectively ${ }^{4}$. Furthermore, the European Commission defines thematic priorities that should be targeted in each MFF that range from fostering human capital to increasing accessibility by building new infrastructure (Section 4 and 5 provide more details on this).

8. In the first stage of the distribution process, each member state has to prepare a "national strategic reference framework", i.e. a strategy on the areas that should be prioritised in the specific regions during the particular programming period and how much money is necessary to achieve progress 5 . Moreover, each member state suggests a list of operational programmes (OP $)^{6}$ which provide details on the distribution of funds across types of funds (ERDF, ESF and CF), thematic priorities and (mostly) NUTS2 regions. In the next stage, the documents undergo a review process by the European Commission and national authorities.

9. The operational programmes serve as the organisational basis on which regional or national (private or public) managing authorities implement the EU's cohesion policy. They do so by co-financing

\footnotetext{
${ }^{3}$ See http://ec.europa.eu/budget/figures/fin fwk0713/fwk0713 en.cfm\#cf07 13.

${ }^{4}$ Only regions with a GDP below $75 \%$ below the EU-25 average are eligible for funds under the Convergence objective.

${ }^{5}$ For a more detailed description of the rules of implementation, refer to (European Council, 2006).

${ }^{6}$ For a complete list of operational programmes on which the database is based, see Bachtrögler et al. (2017b).
} 
appropriate projects, together with additional national public funds ${ }^{7}$. Private firms and public institutions can apply for project funding and the managing authorities select promising projects.

10. Thus, while member states negotiate overall strategies and the total amount of funds per country and operational programme with the European institutions, the selection of projects and distribution of funds to beneficiary firms is a responsibility of national or regional managing authorities. Since 2007, lists of beneficiaries, which are the basis for the database discussed in this report, have to be made publicly available (Article 7 in European Commission, 2006).

\section{Literature review}

11. This section provides an overview on studies that evaluate the effects of cohesion policy, on either regional (or a country's) characteristics, on the one hand, or on the beneficiary firms on the other hand.

\section{Aggregate analysis}

12. The aim of most studies is to draw conclusions on whether EU cohesion policy leads to convergence of incomes or income growth among regions. Although cohesion policy supports single beneficiary firms and institutions, consequently, if the policy is successful, there should be a catching-up process by less developed regions. The most common unit of observation of these studies is the European NUTS2 region, a geographical area with between 800,000 and 3 million residents.

13. The evidence on the impact of cohesion policy seems to be mixed (for a survey of mostly econometric studies see for example Hagen and Mohl, 2009, Pienkowski and Berkowitz, 2016 or Dall'Erba and Fang, 2017). While some studies find a positive conditional effect of cohesion policy on regional growth or convergence (Becker, et al., 2013; Capellen, et al., 2003; Ferrara et al., 2016), others claim an even negative effect (Breidenbach, et al., 2016). More recently, studies have begun to exploit more disaggregated data and to assess how differences among regions and types of funding play a role on the impact of cohesion policy. To name the first study of this type, Rodriguez-Pose and Fratesi (2004) study the effects of different types of funding on regional growth. They conclude that projects that relate to human capital formation and labour market spending foster regional growth in the medium run, while infrastructure investments or commitments to agricultural support and rural restructuring do not.

14. A large strand of the literature studies the "absorptive capacity", i.e. which regional characteristics matter for cohesion policy effectiveness. Institutional quality (Capellen, et al., 2003; Bachtler, et al., 2014; Rodríguez-Pose \& Fratesi, 2013) and the stock of human capital (Becker, et al., 2013), have been shown to be determining factors for the success of cohesion policy at the regional level. The positive overall effects of funding on regional growth become larger, when the quality of government is high and when the human capital stock is high. Papers that incorporate potential spatial spillovers or geographic proximity of treated regions to large economic centers (Gagliardi \& Percoco, 2017; Dall'Erba and Le Gallo, 2008; Breidenbach, et al., 2016, Maynou, et al., 2016; Percoco, 2013) come to mixed conclusions about the effectiveness of cohesion policy with regard to regional growth. If positive effects are found, they are limited to fewer areas.

15. A handful of papers assesses the effect the Great Recession might have had on the effectiveness of cohesion policy. Bachtrögler (2016) and Becker et al. (2018) find that the effectiveness of cohesion policy decreased during the economic crisis compared to before. Reasons for that may be the more difficult political legitimation to conduct structural policies in times of economic downturn and increasing

\footnotetext{
${ }^{7}$ Regulations on maximum co-financing rates and eligible expenditure can be found in (European Council, 2006).
} 
unemployment (Camagni and Capello, 2015), which becomes visible in a delayed absorption of the committed funds.

\section{Firm-level analysis}

16. Recently, as richer data has become available, firms have become more interesting as unit of observation for research on cohesion policy evaluation. Most studies focus on a small number of regions. Bondonio and Greenbaum $(2006,2014)$ focus on (former) "Objective 2" regions in Northern and Central Italy and find that payments by the ERDF had a positive influence on employment growth, however, at a relatively high cost per job. The effects of cohesion policy on firm-level productivity in the European manufacturing sector can be found in (Fattorini, et al., 2018). While they combine firm-level data with regional ERDF data, they cannot distinguish between beneficiary firms and non-beneficiary firms.

17. While, so far, studies did not distinguish between actual beneficiaries and non-beneficiaries, Maroshegyi and Nagy (2010) contribute to this literature by conducting interviews in Hungarian SME beneficiary firms. They conclude that "SME owners count EU-funding as a mixed blessing" and most small and medium-sized enterprises (SME) experienced some difficulties in obtaining the EU-funds and successfully implementing the projects. There seem to be, however, some positive effects on sales for these firms, which helped them especially during the financial crisis. Bernini and Pellegrini (2011) study beneficiaries in Southern Italy between 1996 and 2004. They also find positive short-run effects for beneficiary firms in terms of employment, output and asset growth but less growth of total factor productivity compared to non-beneficiary firms. Another study that identifies beneficiaries, not of EU funding but other national business programmes, is Hartsenko and Sauga (2012). They employ a sample of Estonian firms and find positive effects on firm sales due to government subsidies.

18. Finally, Bachtrögler, et al. (2017a) is one of the first papers that utilises a sample of manufacturing firms in different countries for the period 2007-2013, where the beneficiaries of EU cohesion policy are known. Their findings are in line with earlier work as they also confirm positive effects on employment and value-added growth but smaller or insignificant changes in productivity. However, they show that those effects are not uniform across European countries and regions. Moreover, comparing the estimated treatment effects across regions with different firm dynamics shows that the effects of cohesion policy on manufacturing firms' value added and employment growth tend to be higher in regions with a more dynamic, more competitive business environment (OECD, 2017). Benkovskis et al. (2018) use a Latvian firm-level dataset and find that ERDF projects seem to raise the capital-to-labour ratio and employment of beneficiaries in the short run and the medium run. In the short run, they confirm that there is no average effect on TFP. With some time lag, however, there is some evidence for small positive effects and they are more likely found in bigger firms and firms that were less productive before the treatment. Table 1 summarizes some dimensions of the firm-level literature. 
Table 1. Firm-level literature overview

\begin{tabular}{l|l|l|l|l}
\hline Author(s) & Unit of Observation & Geography & Time & Funds \\
\hline $\begin{array}{l}\text { Bondonio and Greenbaum } \\
\text { (2006) }\end{array}$ & $\begin{array}{l}\text { aggregated SMEs in } \\
\text { provinces for } \\
\text { different sectors }\end{array}$ & $\begin{array}{l}\text { Northern and } \\
\text { Central Italy }\end{array}$ & $\begin{array}{l}1995 \text { and } \\
1998\end{array}$ & $\begin{array}{l}\text { Objective 2 regions } \\
\text { business incentives }\end{array}$ \\
\hline Maroshegyi and Nagy (2010) & SME firms & Hungary & $2004-2006$ & ECOP 2.1.1 and JEREMIE \\
\hline Bernini and Pellegrini (2011) & manufacturing firms & Southern Italy & $1996-2004$ & $\begin{array}{l}\text { Italian state aid Law } \\
488 / 1992 \text { (L. 488) }\end{array}$ \\
\hline Hartsenko and Sauga (2012) & Firms & Estonia & 2004-2010 & Enterprise Estonia (EAS) \\
\hline $\begin{array}{l}\text { Bondonio and Greenbaum } \\
\text { (2014) }\end{array}$ & Firms & Northern Italy & $2000-2003$ & ERDF \\
\hline Bachtrögler, et al (2017a) & Manufacturing firms & $\begin{array}{l}\text { FR, IT, ES, RO, } \\
\text { CZ, PT, SK }\end{array}$ & $\mathbf{2 0 0 7 - 2 0 1 5}$ & ERDF, ESF, CF \\
\hline Benkovskis et al. (2018) & Firms & Latvia & $2007-2015$ & ERDF (ESF, CF) \\
\hline Fattorini, et al. (2018) & Manufacturing firms & EU28 & $2007-2015$ & ERDF \\
\hline
\end{tabular}

\section{Data}

\section{Description of the database}

19. To the best of our knowledge, the present database is the most comprehensive data collection on individual projects financed by the European structural and cohesion funds for the Multiannual Financial Framework 2007-2013. We collected the data on the projects and their co-funding structure between 2015 and 2017 from official documents ("list of beneficiaries") that are published by the national or regional managing authorities of the operational programmes. The data collection was a tedious and lengthy process. The data was collected from approximately 300 lists in 25 different countries, in some cases when no list of beneficiaries was publicly available on the website, we had to get in touch with the relevant authority to request the information. Not all of them responded. Moreover, unfortunately, the lists of beneficiaries are not standardised. They are published on a multitude of different formats (e.g. excel, PDF, word documents) and are mostly written in the national language, which required substantial processing and work in terms of translation.

20. The database consists of over two million observations for the period 2007-2013. Each observation represents a project co-funded by one of the structural funds (ERDF, ESF) or the Cohesion Fund (CF) in one of $25 \mathrm{EU}$ member states, except Hungary and Greece ${ }^{8}$. Approximately one million different beneficiaries carried out those projects. The project information includes the name and/or a description of the project, the name of the beneficiary firm or institution, the country and NUTS region in which the project takes place (mostly at the NUTS2-level, except for Germany, the Netherlands and the United Kingdom that design their regional operational programmes for NUTS-1 regions) as well as the type of fund, which co-funds the project (ERDF, ESF, CF). Besides this information, the database also includes the corresponding objective (i) cohesion and (ii) regional competitiveness and employment as well as a thematic category (Table 2). As not all lists of beneficiaries include information on the thematic category of the project, we used machine learning-techniques in order to identify this information and succeeded for almost all observations in the database. ${ }^{9}$

\footnotetext{
${ }^{8}$ To the best of our knowledge, at the time of data collection, Hungary did not publish the lists of beneficiaries. Modest project funding did not allow us to translate Greek lists of participants.

${ }^{9}$ For more details about the use of machine learning-techniques, see the Appendix and Bachtrögler et al. (2017b). For more detailed corresponding theme subcategories, see the Appendix.
} 
Table 2. Thematic categories for the projects

\begin{tabular}{|c|c|c|}
\hline Capacity Building & $\begin{array}{c}\text { Innovation \& Research, Technology and } \\
\text { Development }\end{array}$ & Rail \\
\hline Culture, Heritage and Tourism & IT Services and Infrastructure & Road \\
\hline Energy & Labour Market & Social Inclusion \\
\hline Environment & Other SME and Business Support & Social Infrastructure \\
\hline Human Capital & Other transport & Urban and Territorial Dimension \\
\hline
\end{tabular}

21. Furthermore, the database includes data on the projects' funding structure. For each observation, we know at least one, committed or paid-out value that is provided by the EU funds. Some lists include information on both commitments and payments (very few include information on the date of commitment and payment), or do not only specify the co-funding by structural funds or the CF but also the amount of co-funding by national public resources as well as the financial contribution of the beneficiary itself. We calculate every project total value as the sum of all co-funding by the EU, national or regional authorities, as well as the funding provided by beneficiaries themselves.

22. To learn more about the characteristics of the successful project applicants, the project-level data described above is merged with ORBIS business database (Bureau van Dijk) using the beneficiaries' name. We were able to match about $40 \%$ of all projects (or $30 \%$ of individual beneficiaries) with business data using the online matching algorithm of ORBIS. ${ }^{10}$ For the remaining firms, the ORBIS algorithm could not find a match. There are some drawbacks to the ORBIS database (see Kalemli et al., 2015). Among other things, it concerns the varying degree of detail across countries. One reason is that the requirements for reporting differ across countries. With that, there is an underrepresentation of small firms that varies across countries (see Gal, 2013). Further, firms are deleted when there is no reporting for a number of years, even if the firm still operates. Sometimes, BvD identification numbers (ID) might change for a number of reasons. In those cases, it is not always guaranteed that the firm can be tracked consistently over time. Despite these drawbacks, Orbis is still the largest, most comprehensive cross-country dataset on detailed firm-level information. It contains millions of company accounts that cover not only large, listed companies - as is the case for popular alternative data sources - but small, privately owned ones.

23. For the purpose of the present paper, we extract data on the location of the firms, their founding year, the number of employees, their legal form and if they are part of a corporate group. Furthermore, financial information such as operating revenue, value added, fixed assets, (tangible) fixed assets and the cost of employees are also collected.

24. Table 3 shows the list of variables included in the merged database, the coverage of each variable as a percentage of all observations, the source of the data and a short description of the variables. The upper panel shows project-level information that is contained in the lists of beneficiaries, while the lower part lists variables from the ORBIS database. Due to low coverage of some variables, the subsample that can be considered is therefore relatively small depending on the research question. It is, however, still substantially larger and more recent than in other studies.

25. All project information including the committed or paid-out amounts lacks a time dimension, so they represent a cross section for the MFF 2007-2013. Although the MFF ends in 2013, projects can receive payments up to two years after the end of the period. Since data collection for the present database took place between 2015 and 2017, the lists of beneficiaries should include also payments made after $2013 .{ }^{11}$ While project information is cross-sectional, any financial information from ORBIS, as well as the number of employees are time series from years prior to the treatment (2006 if available) to the most recent data point (2016 at the latest).

\footnotetext{
${ }^{10}$ See the appendix for more information.

${ }^{11}$ For exact reporting dates by operational programmes, see Bachtrögler et al. (2017b).
} 
Table 3. Coverage (in \%) and description of variables in database

\begin{tabular}{|c|c|c|c|}
\hline Variable & Coverage & Source & Description \\
\hline \multicolumn{4}{|l|}{ Project information } \\
\hline Beneficiary & 100 & LoB & Name of the beneficiary firm/institution \\
\hline Country (NUTS 0) & 100 & LoB & Country ISO code (2 digit) \\
\hline Region (NUTS 1, 2) & 97 & $\begin{array}{l}\text { LoB, } \\
\text { Orbis, oc }\end{array}$ & NUTS1 code (3 digit) or NUTS2 code (4 digit) \\
\hline Type of fund & 100 & LoB & ERDF, ESF, CF \\
\hline Objective & 100 & LoB & $\begin{array}{l}\text { 'Regional competitiveness and employment' or } \\
\text { 'Convergence' }\end{array}$ \\
\hline Theme & 83 & LoB, oc & Thematic category (15 categories) of a project \\
\hline $\begin{array}{l}\text { Operational } \\
\text { programme }\end{array}$ & 99 & LoB & $\begin{array}{l}\text { Programme code that defines main objectives and overall } \\
\text { co-funding for a specific region or country. }\end{array}$ \\
\hline Project name & 67 & LoB & Name of the co-funded project. \\
\hline Project description & 39 & LoB & Description of the co-funded project. \\
\hline Project start & 19 & LoB & Date of project start \\
\hline Project end & 14 & LoB & Date of project end \\
\hline Commitments EU & 15 & LoB & Committed co-funding by the EU \\
\hline $\begin{array}{l}\text { Commitments } \\
\text { national }\end{array}$ & 5 & LoB & Committed co-funding by the national/regional authority \\
\hline Commitments benef & 2 & LoB & Committed funding by the beneficiary \\
\hline Commitments sum & 74 & LoB & Committed sum (EU+national+beneficiary) \\
\hline Payments EU & 15 & LoB & Actual paid co-funding by the EU \\
\hline Payments national & 3 & LoB & Actual paid co-funding by the national/regional authority \\
\hline Payment sum & 49 & LoB, oc & Actual paid co-funding sum (EU+ national) \\
\hline Total value & 99 & LoB, oc & $\begin{array}{l}\text { Total value of a project (EU+national+beneficiary). If } \\
\text { payments are available, the sum is built with the payments, } \\
\text { otherwise with commitments. }\end{array}$ \\
\hline Year of approval & 59 & LoB & Year of project approval by the national/regional authority \\
\hline \multicolumn{4}{|c|}{ Business information (ORBIS) } \\
\hline Name & 39 & Orbis & Name of the company \\
\hline Zip code & 35 & Orbis & Zip code \\
\hline City & 36 & Orbis & City \\
\hline NUTS & 30 & Orbis & NUTS 2 code \\
\hline Year founded & 32 & Orbis & Year the company was founded \\
\hline Street & 35 & Orbis & Street addresse \\
\hline Nace & 33 & Orbis & NACE industry \\
\hline Number cooperate & 17 & Orbis & Number of companies in corporate group \\
\hline $\begin{array}{l}\text { Number of } \\
\text { employees }\end{array}$ & 18 & Orbis & Most recent number of employees \\
\hline Mother & 7 & Orbis & Name of mother company \\
\hline Legal & 11 & Orbis & Legal form of the company (274 forms) \\
\hline Entity & 11 & Orbis & Type of entity ( 9 types) \\
\hline Employment & 9 & Orbis & Number of employees \\
\hline Operating revenue & 9 & Orbis & Operating revenue (turnover) \\
\hline $\begin{array}{l}\text { Tangible fixed } \\
\text { assets }\end{array}$ & 8 & Orbis & Tangible fixed assets assets \\
\hline Fixed assets & 8 & Orbis & Sum of tangible, intangible and other fixed assets \\
\hline Cost of employees & 6 & Orbis & Cost of employees \\
\hline Value added & 6 & Orbis & Value added \\
\hline
\end{tabular}

\section{Stylised facts}

26. This section presents stylised facts about the projects carried out during 2007-2013. We first show firm characteristics of recipient firms and institutions by country and region. Then, we examine different patterns by funding instrument (ERDF, ESF, CF) across project sizes, firm sizes, industries and 
themes. All figures and tables are constructed with the respective subset limited by data availability (refer to Table 3) and thus represent only beneficiary firms and institutions unless stated otherwise (the last subsection refers to the sample used for the estimation of average treatment effects on the treated). Further, in the following, "firms" include all beneficiary firms and (public) institutions. Not all tables include Malta, Luxembourg, Croatia and Ireland since the number of observations is very small and even smaller for the data from ORBIS.

\section{Stylised facts: Differences by EU member country or region}

27. Table 4 lists the distribution of projects and beneficiaries across countries in column 1 and 2 . Column 3 lists the subsample of firms for which information was available in ORBIS. We also show the average number of employees of beneficiary firms over the period 2007-2013 in column 4.

Table 4. Country distribution: number of projects, firms and average firm size

1

\begin{tabular}{|c|c|c|c|c|}
\hline & $\begin{array}{l}\text { Total number of } \\
\text { projects }\end{array}$ & $\begin{array}{l}\text { Total number of } \\
\text { beneficiary firms }\end{array}$ & $\begin{array}{l}\text { Sample of matched } \\
\text { beneficiary firms } \\
(\text { ORBIS) }\end{array}$ & $\begin{array}{l}\text { Average number of } \\
\text { employees } 2007-2013 \\
\text { in beneficiary firms }\end{array}$ \\
\hline Austria & 77,103 & 43,003 & 784 & 327 \\
\hline Belgium & 4,398 & 2,139 & 1,812 & 217 \\
\hline Bulgariat & 668 & 326 & 216 & 378 \\
\hline Croatia & 877 & 698 & 187 & NA \\
\hline Czech Republic & 70,323 & 28,062 & 19,540 & 88 \\
\hline Germany & 429,469 & 214,047 & 43,315 & 120 \\
\hline Denmark & 598 & 265 & 213 & 692 \\
\hline Estonia & 16,288 & 9,553 & 7,441 & 28 \\
\hline Spain & 653,120 & 517,240 & 77,930 & 56 \\
\hline Finland & 19,935 & 13,420 & 11,460 & 24 \\
\hline France & 102,170 & 25,983 & 19,519 & 218 \\
\hline Ireland & 4,863 & 4,292 & 0 & NA \\
\hline Italy & 405,486 & 99,926 & 52,100 & 42 \\
\hline Latvia & 8,216 & 2,789 & 2,705 & 61 \\
\hline Lithuania & 8,325 & 2,789 & 2,715 & 105 \\
\hline Luxembourg & 102 & 42 & 8 & NA \\
\hline Malta & 252 & 152 & 9 & NA \\
\hline Netherlands & 9,157 & 5,666 & 4,839 & 246 \\
\hline Poland & 150,571 & 56,476 & 28,458 & 97 \\
\hline Portugal & 52,700 & 24,536 & 15,796 & 66 \\
\hline Romania & 15,641 & 11,913 & 6,841 & 67 \\
\hline Sweden & 4,458 & 1,909 & 817 & 797 \\
\hline Slovenia & 4,992 & 2,359 & 1,510 & 79 \\
\hline Slovak Republic & 10,186 & 4,686 & 3,910 & 99 \\
\hline United Kingdom & 5,477 & 2,877 & 2,103 & 407 \\
\hline TOTAL & $2,055,375$ & $1,075,854$ & 304,228 & \\
\hline
\end{tabular}

* Note that the number of firms per country listed in this column does not take into account the availability of financial or other data. It only shows how many firms are matched. ${ }^{\top}$ At the time of data collection, only 2 of 7 lists of beneficiaries were available for Bulgaria.

28. In general, larger economies (Germany, France, Italy) seem to have a larger number of beneficiaries although there are some exceptions such as the United Kingdom. There are many potential explanations for those exceptions. 
29. First, the principle eligibility of countries and regions for funds, not every country or region will receive the same amount of co-funding. On average, more money is allocated to less developed regions (see Figure 1). This means that a country such as the United Kingdom receives relatively less and thus has relatively fewer beneficiaries. On the other hand, British beneficiaries are on average larger in terms of employees.

Figure 1. Total values relative to regional GDP

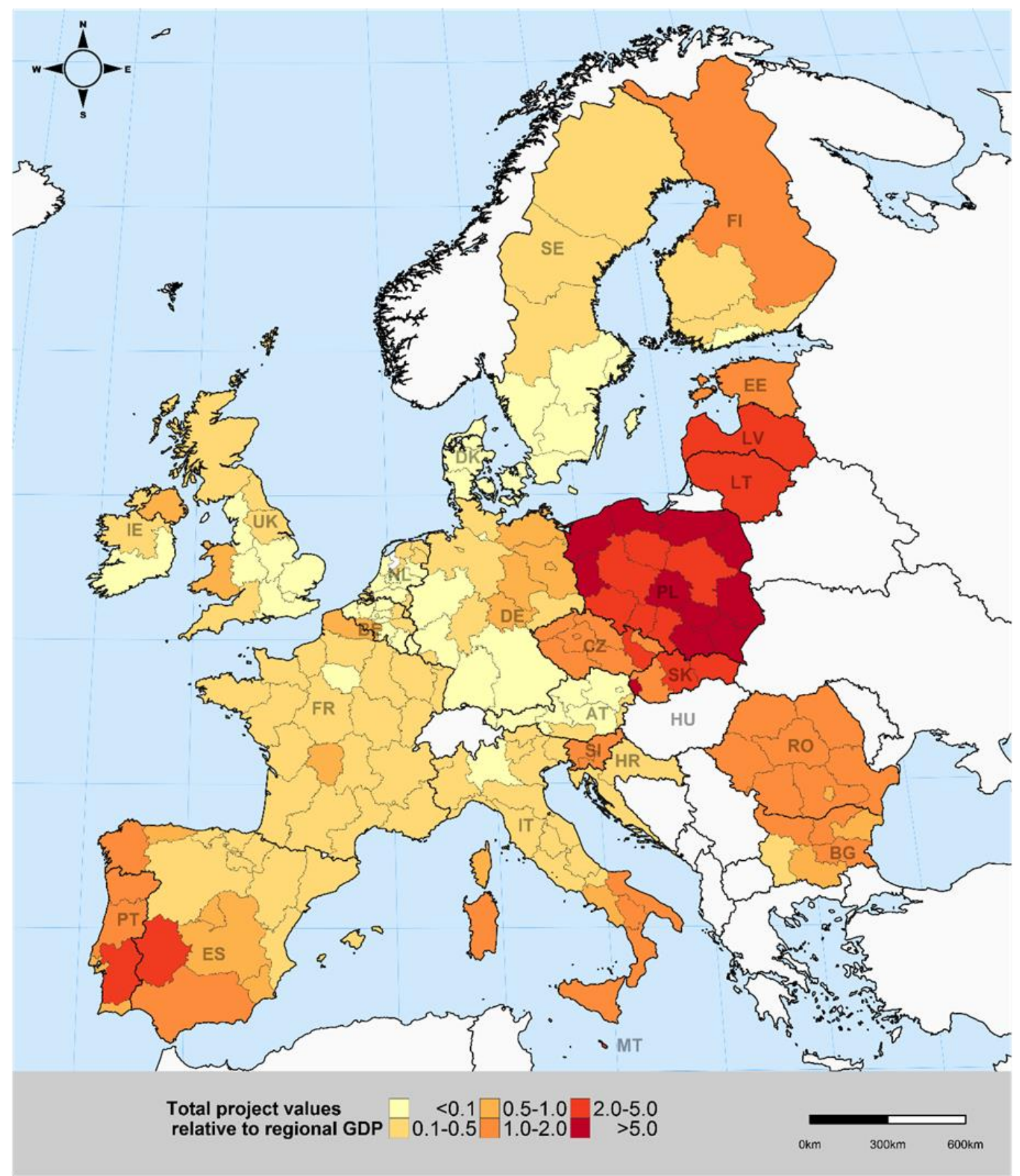

30. Second, operational programmes are designed for different regions, have different main objectives and priorities and thus will co-fund different types of projects. The United Kingdom is an example where there are only 2,800 beneficiaries with an average of 407 employees. Contrarily, in Spain over 600,000 projects were carried out by firms with an average number of employees of only 56. 
31. Beneficiary firms are not only unevenly distributed across European regions, they also differ in many of their characteristics. Table 5 compares the average value added as well as the average operating revenue (turnover) across countries for the subsample of matched firms. The characteristics might not be representative of the population of (beneficiary) firms as small firms are usually underrepresented in ORBIS. The table shows that the average beneficiary firm differs quite substantially. Dutch, Austrian and British beneficiaries' rank first, second and third with respect to average value added, average turnover and average turnover per employee. Although it seems that Baltic firms (especially Estonia and Lithuania) are relatively more productive (column 2), we in fact have very few observations on value-added, which gives a biased picture. The most productive firms in our database, in terms of value-added per employee, are Dutch, German, Belgian, Austrian and British firms. ${ }^{12}$

Table 5. Beneficiaries: Average value added and operating revenue by country.

\begin{tabular}{|c|c|c|c|c|}
\hline & 1 & 2 & 3 & 4 \\
\hline & $\begin{array}{l}\text { Average } \\
\text { value added } \\
2007-2013\end{array}$ & $\begin{array}{l}\text { Average value added } \\
\text { per employee } \\
2007-2013\end{array}$ & $\begin{array}{l}\text { Average } \\
\text { operating revenue } \\
2007-2013\end{array}$ & $\begin{array}{l}\text { Average operating } \\
\text { revenue per employee } \\
2007-2013\end{array}$ \\
\hline Austria & 46,968 & 143.63 & 101,198 & 309.47 \\
\hline Belgium & 38,265 & 176.34 & 57,540 & 265.16 \\
\hline Bulgaria & 13,863 & 36.67 & 29,340 & 77.62 \\
\hline Czech Republic & 3,726 & 42.34 & 8,433 & 95.83 \\
\hline Germany & 22,710 & 189.25 & 26,037 & 216.98 \\
\hline Denmark & 20,255 & 29.27 & 48,925 & 70.70 \\
\hline Estonia* & 13,348 & 476.71 & 2,673 & 95.46 \\
\hline Spain & 2,949 & 52.66 & 12,399 & 221.41 \\
\hline Finland & 2,347 & 97.79 & 4,206 & 175.25 \\
\hline France & 14,108 & 64.72 & 38,488 & 176.55 \\
\hline Italy & 3,659 & 87.12 & 8,954 & 213.19 \\
\hline Lithuania* & 26,061 & 248.20 & 8,380 & 79.81 \\
\hline Latvia & 4,417 & 72.41 & 4,108 & 67.34 \\
\hline Netherlands & 138,448 & 562.80 & 201,886 & 820.67 \\
\hline Poland & 5,121 & 52.79 & 16,507 & 170.18 \\
\hline Portugal & 2,960 & 44.85 & 12,603 & 190.95 \\
\hline Romania & 1,257 & 18.76 & 4,818 & 71.91 \\
\hline Sweden & 9,413 & 11.81 & 27,866 & 34.96 \\
\hline Slovenia & 4,721 & 59.76 & 11,510 & 145.70 \\
\hline Slovak Republic & 3,955 & 39.95 & 14,668 & 148.16 \\
\hline $\begin{array}{l}\text { United } \\
\text { Kingdom }\end{array}$ & 53,543 & 131.56 & 63,284 & 155.49 \\
\hline
\end{tabular}

32. Figure 2 shows the distribution of average value added of beneficiaries (column 1 in Table 3) across regions. The map highlights that within countries, such as Sweden, Denmark, the UK, France or Germany, there are large cross-regional differences in average value added, showing a slight North-South divide.

12 As Berlingieri et al. (2017) and Andrews et al. (2015) correctly point out, an industry-country average does not necessarily show the complete picture, as the underlying distribution of firm-level TFPs might differ. They show that there is country-industry heterogeneity with respect to the distance of firms to the countries' respective "productivity frontier". 
Figure 2. Average value added in thousand EUR

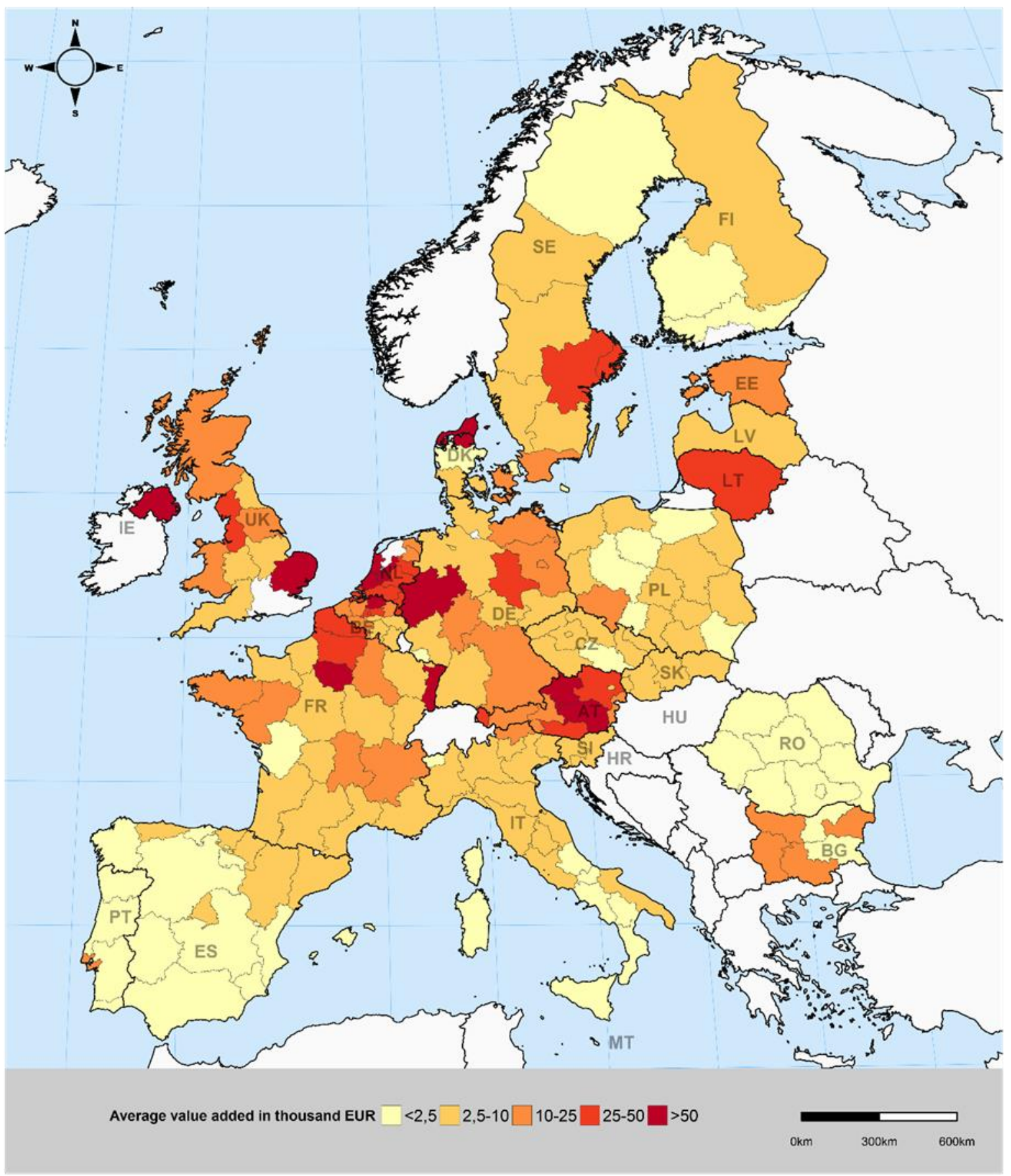

33. The following bar charts show the distribution of total project values for some firm characteristics where the sum of total values is normalised to $1 .{ }^{13}$ Figure 3 and Figure 4 make clear that, while there is some variation between countries, the largest share of projects in terms of value are carried out by firms with the most fixed assets or the highest capital-labour ratio (fixed assets per employee).

${ }^{13}$ The figures are based on the subsample that was matched with ORBIS. 
Figure 3. Distribution of total values by country and quintile of fixed assets

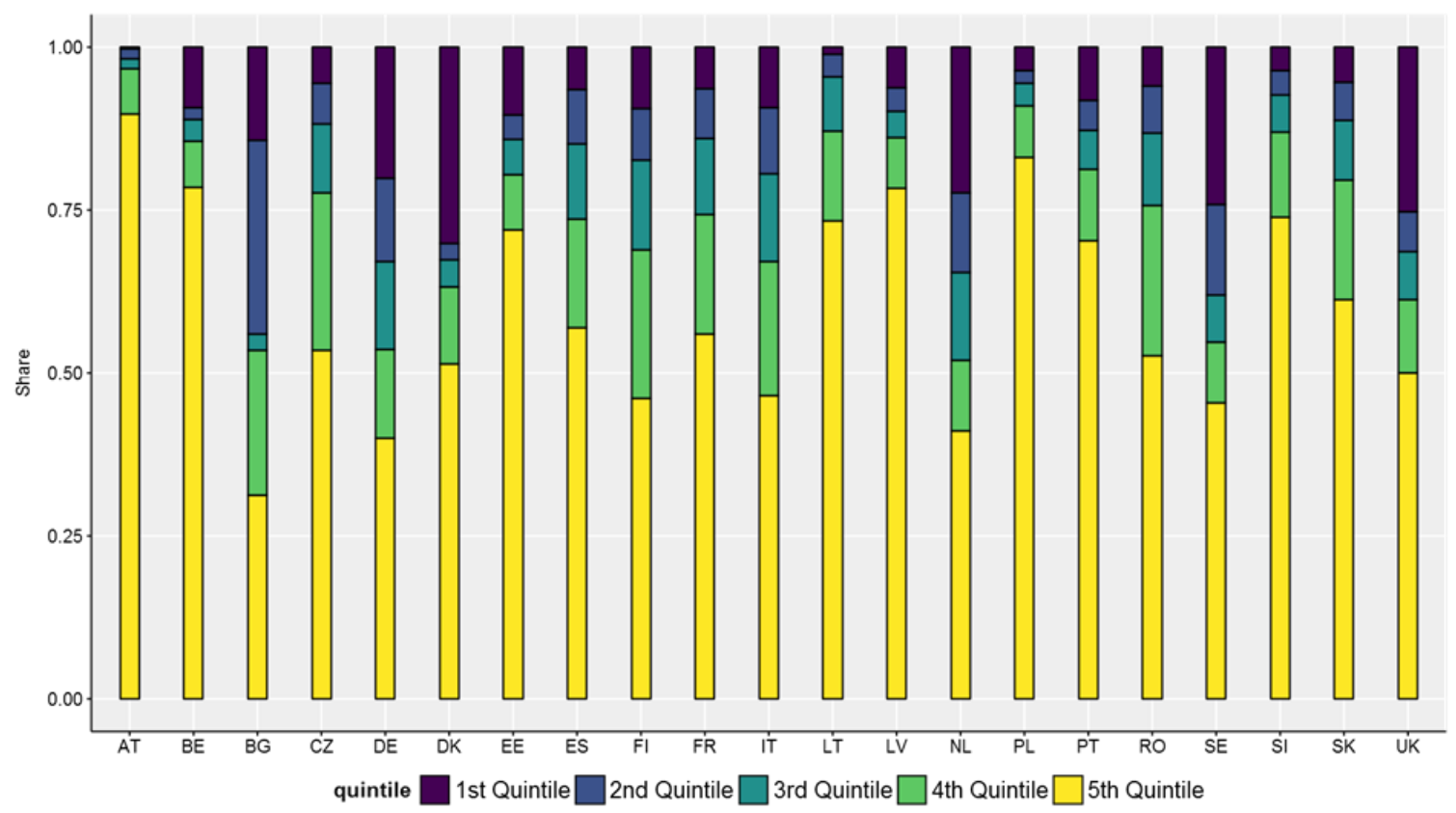

Figure 4. Distribution of total values by country and quintile of capital-labour ratio

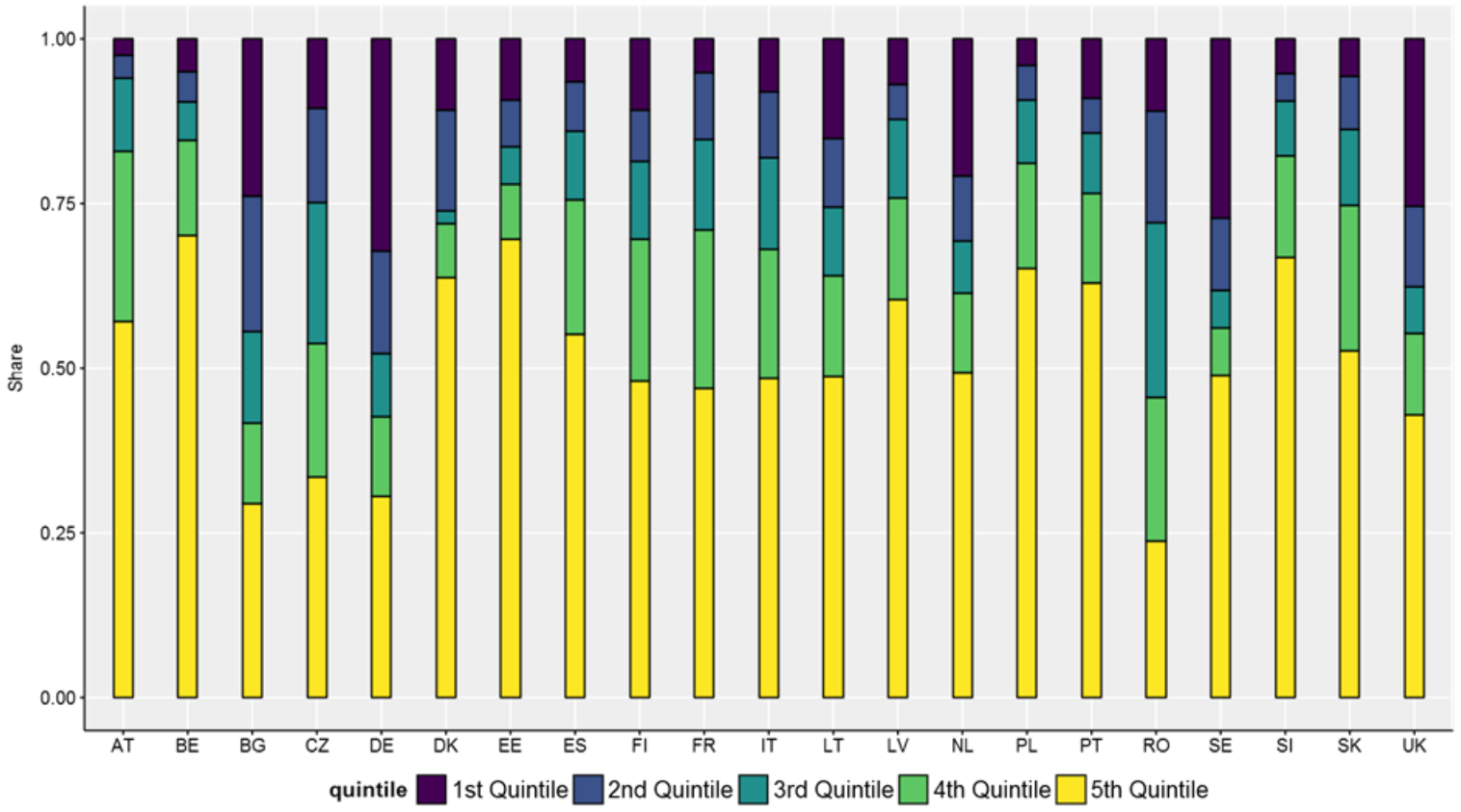


Figure 5. Distribution of total values by country and firm size

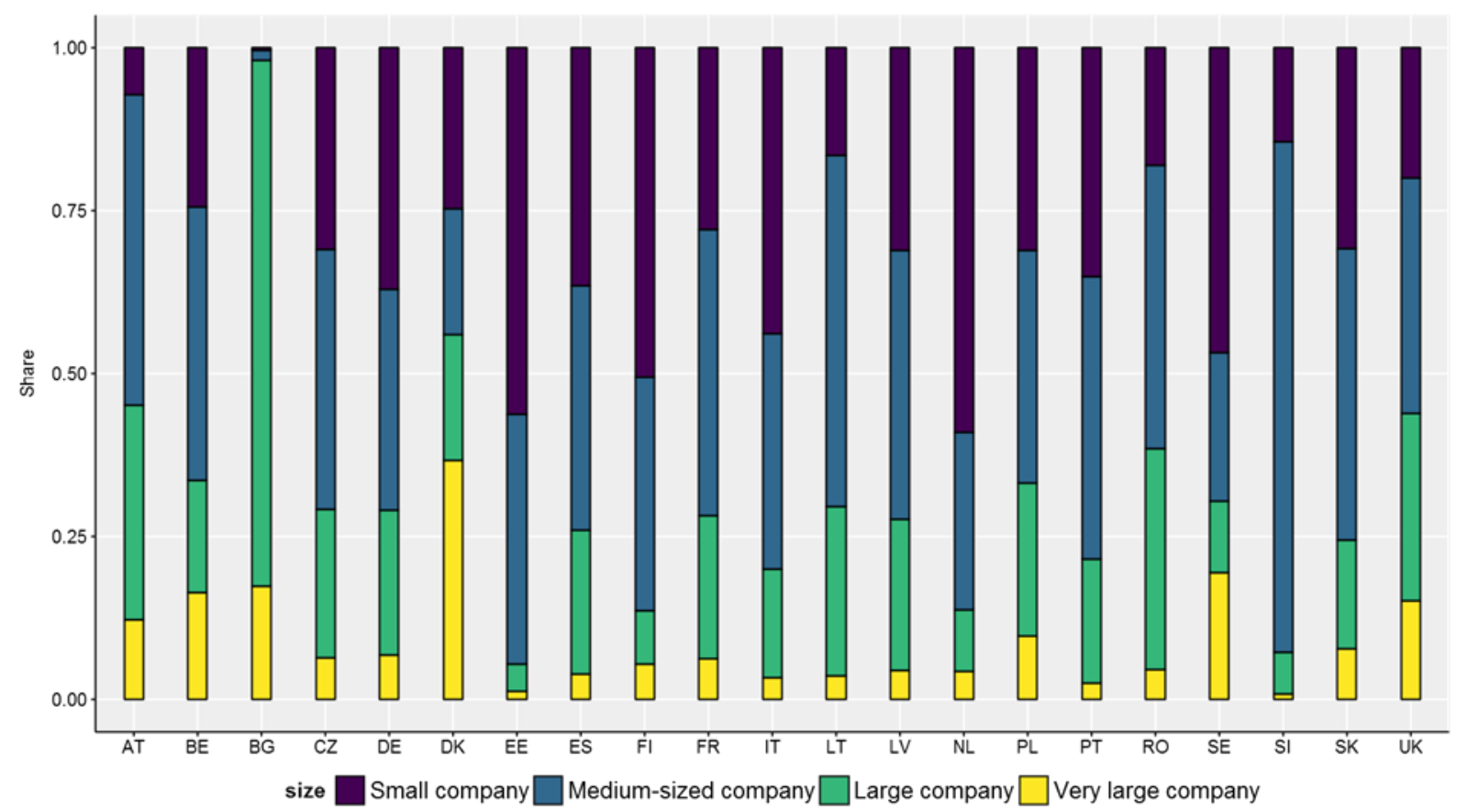

34. Interestingly, Figure 5 shows that those firms are not necessarily also the largest in terms of number of employees and operating revenue. ${ }^{14}$ The variation of firm size across countries again points to a different overall structure of projects in the respective countries. Bachtrögler et al. (2017b) show that, conditional on further firm- and project-level characteristics, larger firms on average carry out projects of higher value. While in Denmark a third of the total project value is attributed to very large firms, in Estonia or Slovenia it is no more than 2 percent.

35. While beneficiaries are different in size and in their capital intensity, they also differ in the industry in which they mainly operate. Table 6 reports the shares of total project values across 20 NACE Rev. 2 industries (A-S). For example, projects in Austria that are carried out by manufacturing firms (C) represent $70 \%$ of the sum of total values of all co-funded Austrian projects. In general, manufacturing firms (C) and public authorities (O) are responsible for the largest share of project values on average, followed by professional and scientific services $(\mathrm{M})$ and projects related to water management $(\mathrm{E})$. The remaining project sums are on average relatively evenly distributed, however, there again is large variation across countries. Keeping in mind that the database only includes lists of beneficiaries for two Bulgarian operational programmes, the reported firms in Bulgaria are exclusively public authorities.

\footnotetext{
${ }^{14}$ ORBIS firm size categories: Very large companies: 1,000 or more employees, large companies: 150 or more employees, medium-sized company: 15 or more employees, small company: all others. Small firms are usually underrepresented in ORBIS.
} 
Table 6. Distribution (shares in \%) of total project values by country and industry

\begin{tabular}{|c|c|c|c|c|c|c|c|c|c|c|c|c|c|c|c|c|c|c|c|}
\hline & A & B & C & D & $\mathbf{E}$ & $\mathbf{F}$ & G & $\mathbf{H}$ & $\mathbf{I}$ & J & $\mathbf{K}$ & $\mathbf{L}$ & $\mathbf{M}$ & $\mathbf{N}$ & 0 & $\mathbf{P}$ & $\mathbf{Q}$ & $\mathbf{R}$ & $\mathbf{S}$ \\
\hline Austria & & & 70 & & & 2 & 4 & 1 & 5 & & 4 & & 5 & 3 & 4 & & & & \\
\hline Belgium & & & 27 & & 1 & 6 & 8 & 4 & 2 & 1 & 13 & 3 & 5 & 6 & 14 & 4 & 2 & 2 & 2 \\
\hline Bulgaria & & & & & & & & & & & & & & & 99 & & & & \\
\hline $\begin{array}{l}\text { Czech } \\
\text { Republic }\end{array}$ & 2 & 2 & 24 & 4 & 3 & 3 & 5 & 2 & 2 & 3 & & 4 & 5 & 2 & 24 & 3 & 3 & 4 & 4 \\
\hline Germany & & & 8 & & & 1 & 3 & 2 & 1 & 2 & 2 & 1 & 14 & 3 & 5 & 12 & 19 & 3 & 24 \\
\hline Denmark & & & 9 & & & 1 & & 2 & 1 & & 4 & 6 & 13 & 5 & 29 & 15 & & 2 & 12 \\
\hline Spain & 2 & & 27 & 1 & 1 & 11 & 10 & 8 & 4 & 4 & 1 & 1 & 10 & 2 & 11 & 3 & 2 & 1 & 3 \\
\hline Finland & 1 & 1 & 28 & 1 & 2 & 4 & 4 & 4 & 2 & 3 & 1 & 6 & 9 & 3 & 12 & 6 & 2 & 3 & 8 \\
\hline France & 1 & & 39 & 11 & 4 & 4 & 8 & 3 & 4 & 4 & 2 & 5 & 9 & 3 & & 1 & 1 & 1 & 1 \\
\hline Italy & 2 & & 30 & 2 & 4 & 7 & 11 & 8 & 5 & 8 & 3 & 3 & 9 & 3 & & 2 & 2 & 1 & 1 \\
\hline Lithuania & & & 15 & 7 & 17 & 1 & 2 & 3 & 2 & 2 & & 2 & 8 & & 12 & 8 & 12 & 3 & 6 \\
\hline Latvia & 1 & 1 & 21 & 10 & 23 & 1 & 2 & 9 & & 4 & & 6 & 10 & 1 & 1 & 1 & 6 & & 4 \\
\hline Poland & & 1 & 26 & 14 & 10 & 4 & 7 & 8 & 2 & 4 & 2 & 3 & 7 & 1 & 2 & 3 & 3 & 2 & 2 \\
\hline Portugal & & 8 & 40 & 1 & 6 & 2 & 5 & 7 & 10 & 6 & & 1 & 4 & 2 & 1 & 3 & 2 & 2 & \\
\hline Romania & 3 & 3 & 43 & & 11 & 8 & 7 & 2 & 1 & 2 & & 2 & 14 & 1 & & 1 & & & \\
\hline Sweden & & & 2 & 2 & & 1 & & 4 & & 3 & 16 & 4 & 22 & 1 & 6 & 13 & 17 & 3 & 5 \\
\hline Slovenia & & & 14 & & & & & & 3 & 5 & & 2 & 31 & & 30 & 2 & 4 & 6 & 1 \\
\hline $\begin{array}{l}\text { Slovak } \\
\text { Republic }\end{array}$ & & & 19 & 3 & 2 & 3 & 7 & 5 & 5 & 1 & & 2 & 9 & 4 & 20 & 3 & 7 & 5 & 3 \\
\hline $\begin{array}{l}\text { United } \\
\text { Kingdom }\end{array}$ & & & 12 & 1 & & 6 & 1 & 1 & & 4 & 7 & 4 & 10 & 16 & 15 & 10 & 5 & 3 & 5 \\
\hline All & 1.8 & 2.7 & 23.5 & 4.2 & 8.9 & 3.5 & 5.2 & 4.0 & 3.1 & 3.5 & 4.6 & 3.3 & 10.7 & 3.7 & 17.4 & 5.4 & 5.8 & 3.1 & 6.0 \\
\hline
\end{tabular}

All

Notes: A: Agriculture, Forestry, fishing; B: Mining, quarrying; C: Manufacturing; D: Energy; E: Water supply, sewerage, waste management; F: Construction; G: Wholesale; H:

Transportation; I: Accommodation and food services; J: Information and communication; K: Financial services; L: Real estate services; M: Professional, scientific and technical activities;

$\mathrm{N}$ : Administration and support activities; O: Public administration, defence, social security; P: Education; Q: Human health and social work; R: Arts, entertainment, recreation; S: Other

services. 


\section{Stylised facts: Differences by type of fund}

36. Here we examine how the funds differ with respect to their co-financing structure. Throughout this subsection, we distinguish the Cohesion Fund (CF), the European Regional Development Fund (ERDF) and the European Social Fund (ESF). Additionally there is a category "ERDF_CF" which represents observations that could not be attributed to either of the two, as operational programmes are cofunded by both of them.

37. When we compare the distribution of funds across industries, we can see that the projects cofinanced by the Cohesion Fund are mainly carried out by firms that operate in industries Energy (D), Water (E) and Transportation $(\mathrm{H})$ and these are also the themes of the respective projects. This fits the characteristics discussed above. It is large projects, such as plants and roads, which are co-financed by the $\mathrm{CF}$ and carried out by large firms. ESF projects are relatively small and carried out by smaller firms operating in different private and public service industries. They are mainly focused on the themes Human Capital and Labour Market. The ERDF contributes the most in total. This is because the ERDF has the largest variety of projects that it co-finances. There are projects for every theme co-financed by the ERDF.

Table 7. Distribution of total values of different type of funds across NACE industries

\begin{tabular}{|c|c|c|c|c|}
\hline NACE & CF & ERDF & ERDF_CF & ESF \\
\hline A & 10 & 60 & 21 & 9 \\
\hline B & 8 & 82 & 9 & 1 \\
\hline C & & 92 & 4 & 3 \\
\hline D & 6 & 27 & 68 & 0 \\
\hline$E$ & 19 & 18 & 62 & 1 \\
\hline$F$ & 1 & 85 & 8 & 6 \\
\hline G & 1 & 86 & 3 & 10 \\
\hline $\mathrm{H}$ & 10 & 44 & 43 & 3 \\
\hline I & & 93 & 2 & 5 \\
\hline $\mathrm{J}$ & & 89 & 3 & 7 \\
\hline$K$ & & 89 & 1 & 9 \\
\hline $\mathbf{L}$ & 2 & 81 & 13 & 3 \\
\hline$M$ & 2 & 76 & 10 & 13 \\
\hline $\mathbf{N}$ & 1 & 66 & 8 & 26 \\
\hline 0 & 11 & 47 & 32 & 10 \\
\hline $\mathbf{P}$ & & 39 & 11 & 50 \\
\hline $\mathbf{Q}$ & 1 & 59 & 14 & 25 \\
\hline $\mathbf{R}$ & & 80 & 13 & 7 \\
\hline$S$ & 1 & 54 & 4 & 41 \\
\hline $\mathbf{T}$ & & 30 & & 70 \\
\hline $\mathbf{U}$ & & 90 & & 10 \\
\hline avg & 5.62 & 66.05 & 17.32 & 14.71 \\
\hline
\end{tabular}

Rows may not add to 100 due to rounding errors. 'ERDF\CF' is a category where projects are either co-financed by the ERDF or CF.

Notes: A: Agriculture, Forestry, fishing; B: Mining, quarrying; C: Manufacturing; D: Energy; E: Water supply, sewerage, waste management; F: Construction; G: Wholesale; H: Transportation; I: Accommodation and food services; $\mathrm{J}$ : Information and communication; K: Financial services; L: Real estate services; M: Professional, scientific and technical activities; N: Administration and support activities; O: Public administration, defence, social security; P: Education; Q: Human health and social work; R: Arts, entertainment, recreation; S: Other services, T: Household services. 
Table 8. Distribution of total values of different type of funds across themes

\begin{tabular}{l|c|c|c|c}
\multicolumn{1}{c}{ Theme } & CF & ERDF & ERDF_CF & ESF \\
\hline Capacity Building & & 62 & 6 & 32 \\
\hline Culture heritage and tourism & & 85 & 14 & 1 \\
\hline Energy & & 48 & 52 & \\
\hline Environment & 15 & 38 & 46 & 1 \\
\hline Human capital & & 9 & & 91 \\
\hline Innovation \& RTD & & 92 & 4 & 4 \\
\hline IT services and infrastructure & & 29 & 4 & 35 \\
\hline Labour Market & & 86 & 6 & 70 \\
\hline Other SME and Business support & 32 & 30 & 38 & \\
\hline Other transport & 6 & 20 & 74 & \\
\hline Rail & 3 & 32 & 65 & \\
\hline Road & & 43 & & 57 \\
\hline Social Inclusion & & 86 & 12 & 2 \\
\hline Social infrastructure & & 98 & 1 & 1 \\
\hline Urban and territorial dimension & & & & \\
\hline
\end{tabular}

Rows may not add to 100 due to rounding errors. 'ERDF \CCF' is a category where projects are either co-financed by the ERDF or CF.

\section{The impact of cohesion policy on actual beneficiaries' performance}

\section{Empirical Methodology}

38. This section evaluates whether carrying out a project that is co-funded by the ERDF, the ESF or the CF has an impact on the firm itself. Cohesion Policy can influence firms through various channels. First, there can be demand or scale effects by carrying out large-scale projects that lead to more employment or capital deepening. Additionally projects can lead to improvements in productivity as firms invest in new technology or improve their processes. While these could be already productive firms, the opposite might be the case. Firms could carry out less productive investments that would not have taken place without co-financing. The following analysis sheds some light on the effects of Cohesion Policy on various outcomes at the level of the single beneficiary.

39. The outcome variables, i.e. the firm performance indicators that are expected to be affected by the treatment (by receiving co-funding), taken into account in this study are net job creation as well as a set of characteristics that reflect the firms' productivity and financial position. The latter set of variables includes i) operating revenue per employees (growth), ii) total factor productivity, measured by a calculated Solow residual as explained below, iii) fixed assets which are assumed to reflect the development of the capital stock, iv) fixed assets per employee, as well as v) labour compensation relative to each firm's operating revenue or number of employees respectively. All of these outcomes (except the absolute change in the number of employees) are measured in terms of changes (log differences) from the pre-treatment period (2006 or, if not available, 2007) to the years after the MFF (2014 if available, otherwise later years).

40. The empirical analysis combines propensity score matching and a difference-in-difference approach as in Bachtrögler et al. (2017a). By using this methodology, we can compare the outcome variables in treated firms, i.e. firms which have carried out a co-funded project, and non-treated firms, i.e. the control group. If a firm performance indicator on average has grown faster over the programming period 2007-2013 in the treated firms as compared to the control group, and this difference in outcomes is statistically significant, one can speak of a positive (and significant) treatment effect of the policy on the treated firms.

41. For the estimation of reliable average treatment effects on the treated (ATT), it is necessary to find non-treated firms (which have not received funds in 2007-2013) that are comparable to treated firms 
before the funds receipt, i.e. to account for initial conditions prior to the treatment. Therefore, in the first stage, the probability, or propensity, of a firm to carry out a co-funded project is estimated using logit or probit regression:

$$
p=\operatorname{Pr}\left(T_{i}=1 \mid \boldsymbol{x}\right)=F\left(\boldsymbol{x}_{i 0}^{\prime} \beta\right)
$$

42. In the case of logit estimation, $F($.$) denotes logistic cumulative distribution function, while for the$ probit, the standard normal distribution function is considered (Greene, 2012). The propensity score ranges from zero (zero-probability of receiving funds) to one (100\% probability of being treated).

43. The firms' characteristics included in the vector of explanatory variables $\mathbf{x}$ are their initial (2007 or earlier) number of employees, age, capital-to-labour-ratio (fixed assets per employee), liquidity (current ratio) and value added. Additionally, NUTS-2 region-fixed effects are taken into account in order to control for region-specific unobserved heterogeneity that is not captured by other controls. Moreover, we only compare firms operating in the manufacturing sector and within the same country.

44. In the second stage, similar treated and non-treated firms are matched according to their propensity score using Epanechnikov kernel matching. That is, the whole control group is considered for the comparison; however, propensity scores that are closer to the one of a treated firm each receive higher weights and there is a restriction on the maximum distance between propensity scores. Firms from both the treatment and control group that are off support, i.e. have a propensity score that is smaller than the minimum or larger than the maximum score in the opposite group, are excluded from the matching and comparison exercise.

45. Then, we estimate the expected average difference in each outcome variable y of interest (e.g. net job creation) between the matched firms of the treatment (treatment $\mathrm{T}=1$ ) and control group (treatment $\mathrm{T}=0$ ). The result of this difference-in-difference estimation indicates whether the treated firms have on average experienced a (significant) treatment effect on its firm performance. The average treatment effect on the treated (ATT) is estimated by the following equation.

$$
A T T=E[A T T(p)]=E[E[y(1)-y(0) \mid T=1, p]]
$$

46. According to the conditional independence assumption, it is sufficient to control for the propensity score $\mathrm{p}$ in the difference-in-difference estimation. ${ }^{15}$ Corresponding standard errors are bootstrapped in order to correctly evaluate the significance of estimated ATTs.

47. In order to check the robustness of the results, we consider sub-industry-related (NACE Rev.2 1digit codes) fixed effects in the propensity score estimation and in the estimation of the ATTs. Moreover, we consider characteristics of the projects carried out by the beneficiaries and exclude the smallest projects (with a project value below the fifth percentile of the distribution of total project values) in order to show the validity of results.

\section{Calculation of the Solow residual as measure for total factor productivity}

48. Since total factor productivity (TFP) cannot be observed directly, we have to calculate it for each firm. While there are many ways to calculate or estimate TFP, we follow a very simple procedure based on the idea that the so-called Solow residual represents TFP. The advantage is the possibility to calculate the residual based on ORBIS data and deflators from the OECD STAN database. We follow Gal (2013) who

15 Refer to Angrist and Pischke (2008) for a detailed discussion of propensity score matching and further microeconometric approaches. 
lists the calculation of the Solow residuals as one of many possibilities to measure TFP. Therefore, TFP for firm $i$ is calculated as

$$
T F P_{i}=v a_{i}-\left(1-s_{L}\right) k_{i}-s_{L} l_{i}
$$

where $v a, k$ and $l$ are the natural logarithms of value added, fixed assets (or tangible fixed assets) and employment respectively. ${ }^{16} S_{L}$ is the average share of value added that goes to labour, i.e. the costs of employees relative to value added, for all manufacturing firms in the estimation sample. Monetary figures are deflated using the deflators for value added (value added and labour compensation) and gross fixed capital formation (tangible and total fixed assets) from the OECD STAN database.

\section{Data: Descriptive statistics for the sample of manufacturing firms}

49. For the estimation of the impact of structural funds and the Cohesion Fund on firms' performance, we use the database in conjunction with the estimation approach introduced in Bachtrögler et al. (2017a). They suggest focusing on manufacturing firms due to two reasons: First, they represent the largest share of the sum of total project values per industry (see Section 5.1). Second, in contrast to public authorities, firms within this industry are expected to target similar business objectives and therefore to carry out somewhat similar projects.

50. The subset consists of manufacturing firms in the merged database as well as firms in the same industry and countries that are available in ORBIS (a control group). ${ }^{17}$ As described above, in order to make them comparable with each other, a set of characteristics prior to the funding is taken into consideration (see Table 9). Given data availability, the analysis is done for six European OECD countries, namely, the Czech Republic, Spain, France, Italy, Portugal and the Slovak Republic. ${ }^{18}$

Table 9. Comparison of structural funds beneficiaries and the control group (non-beneficiary firms in the sample) in six OECD countries. Pre-treatment values (2006 if available, otherwise 2007)

\begin{tabular}{|c|c|c|c|c|c|}
\hline Variable & No. of obs. & Mean & Std. Dev. & Min & Max \\
\hline \multicolumn{6}{|c|}{ Number of employees } \\
\hline Beneficiaries & 17,416 & 90.28 & 729.63 & 1.00 & $83,006.00$ \\
\hline Control group & 108,835 & 34.71 & 217.63 & 1.00 & $48,306.00$ \\
\hline \multicolumn{6}{|c|}{ Operating revenue (ths. Euros) per employee } \\
\hline Beneficiaries & 17,413 & 239.07 & 940.19 & 1.87 & $63,118.00$ \\
\hline Control group & 108,821 & 216.63 & 876.11 & 0 & $219,725.50$ \\
\hline \multicolumn{6}{|c|}{ Firm age: From year of incorporation to 2007} \\
\hline Beneficiaries & 17,416 & 18.17 & 13.55 & 1.00 & 127.00 \\
\hline Control group & 108,835 & 16.68 & 12.75 & 1.00 & 130.00 \\
\hline & oductivity ( & $\mathbf{v}$ residual & ed on total & assets & \\
\hline
\end{tabular}

${ }^{16}$ Unfortunately, we are not able to calculate the capital stock using the Perpetual Inventory Method described in Gal (2013) because the ORBIS variable "Depreciation" is only available for 44 firms of the sample. To provide evidence on the consistency of the results, we calculate the Solow residual using total fixed assets and, alternatively, tangible fixed assets.

${ }^{17}$ Note that we exclude observations for which some variables that are required for the matching are missing. Moreover, we limit the sample to firms that were founded before 2007.

${ }^{18}$ Data limitations arise from both the beneficiaries' dataset (number of supported manufacturing firms; e.g. in Germany and the Netherlands only $8 \%$ according to Table 6; data on beneficiaries in the Netherlands and the UK are only available at the NUTS-1 level), the ORBIS matching (see Table 3 which however includes beneficiaries in all industries) as well as the availability of ORBIS data (firm characteristics) that are necessary for the propensity score matching and difference-in-difference estimation. 


\begin{tabular}{|c|c|c|c|c|c|}
\hline Beneficiaries & 12,339 & 5.01 & 1.31 & -1.02 & 14.10 \\
\hline Control group & 79,792 & 5.24 & 1.18 & -3.35 & 13.07 \\
\hline \multicolumn{6}{|c|}{ Total factor productivity (Solow residual) based on tangible fixed assets } \\
\hline Beneficiaries & 12,061 & 4.93 & 1.32 & -1.12 & 13.66 \\
\hline Control group & 76,587 & 5.15 & 1.18 & -3.35 & 13.07 \\
\hline \multicolumn{6}{|c|}{ Value added (ths. Euros) per employee } \\
\hline Beneficiaries & 17,416 & 56.64 & 172.55 & 0.39 & $12,214.67$ \\
\hline Control group & 108,835 & 54.23 & 914.14 & 0.06 & $298,164.00$ \\
\hline \multicolumn{6}{|c|}{ Cost of employees per operating revenue } \\
\hline Beneficiaries & 16,328 & 0.28 & 0.87 & 0.00 & 75.60 \\
\hline Control group & 100,235 & 0.31 & 4.87 & 0.00 & $1,504.33$ \\
\hline \multicolumn{6}{|c|}{ Fixed assets (ths. Euros) } \\
\hline Beneficiaries & 17,416 & $7,421.09$ & $83,838.72$ & 0.50 & $8,354,950.00$ \\
\hline Control group & 108,835 & $2,925.14$ & $67,822.59$ & 0.05 & $13,369,110.00$ \\
\hline \multicolumn{6}{|c|}{ Capital-to-labour-ratio: Fixed assets (ths. Euros) per employee } \\
\hline Beneficiaries & 17,416 & 73.15 & 343.47 & 0.01 & $29,587.67$ \\
\hline Control group & 108,835 & 64.81 & $1,326.71$ & 0.01 & $377,157.30$ \\
\hline \multicolumn{6}{|c|}{ Liquidity: Current ratio } \\
\hline Beneficiaries & 17,416 & 1.72 & 3.01 & 0.05 & 250.86 \\
\hline Control group & 108,835 & 1.90 & 8.55 & 0.00 & $2,221.00$ \\
\hline
\end{tabular}

Note: Observations for which the number of employees, which typically has a very good coverage in ORBIS, is not available prior and after the treatment period 2007-2013 are excluded in the estimation sample and therefore also for the descriptive statistics in this Table. The control group (non-beneficiary firms) only considers firms which are considered (on support) in the propensity score matching, also beneficiaries that are off support are excluded.

Table 10. T-test for the significance of mean differences across the outcome variables of structural funds beneficiaries and the control group
Variable
No. of obs.
Mean
Std. Error
Mean difference and significance

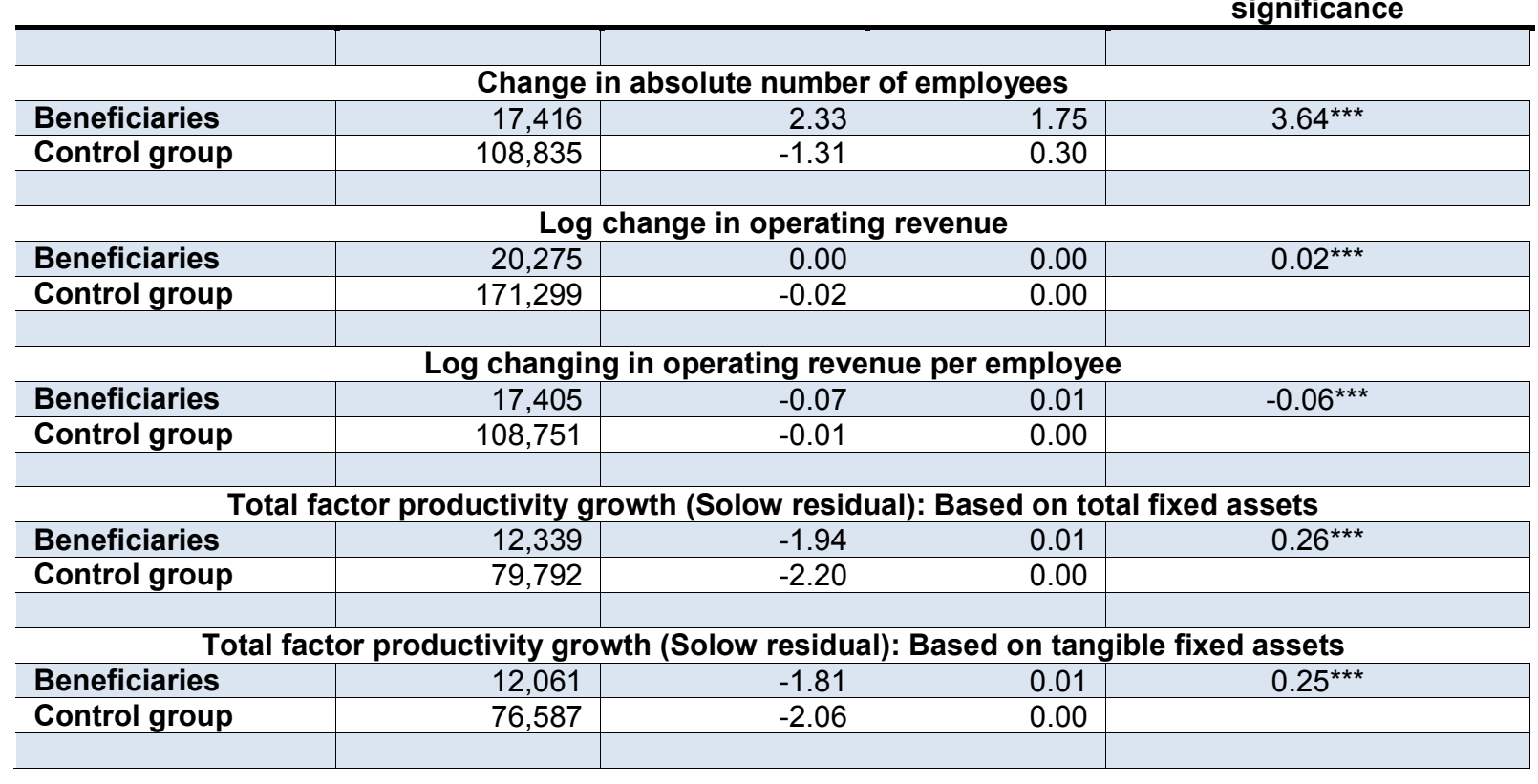




\begin{tabular}{|c|c|c|c|c|}
\hline \multicolumn{5}{|c|}{ Log change in fixed assets } \\
\hline Beneficiaries & 17,981 & 0.33 & 0.01 & $0.26^{* * *}$ \\
\hline Control group & 100,120 & 0.06 & 0.00 & \\
\hline \multicolumn{5}{|c|}{ Log change in fixed assets per employees } \\
\hline Beneficiaries & 17,356 & 0.27 & 0.01 & $0.13^{* * *}$ \\
\hline Control group & 99,834 & 0.14 & 0.00 & \\
\hline \multicolumn{5}{|c|}{ Log change in cost of employees per operating revenue } \\
\hline Beneficiaries & 18,120 & 0.00 & 0.01 & $-0.08^{* * *}$ \\
\hline Control group & 99,942 & 0.09 & 0.00 & \\
\hline \multicolumn{5}{|c|}{ Loq change in cost of emplovees per emplovee } \\
\hline Beneficiaries & 16.273 & -0.07 & 0.01 & $-0.15^{\star * *}$ \\
\hline Control group & 99,690 & 0.08 & 0.00 & \\
\hline
\end{tabular}

51. Table 9 shows that firms that receive treatment, i.e. run a project co-funded by the ERDF, ESF or $\mathrm{CF}$, are on average larger than the other firms in our sample (prior to receiving co-funding). This finding holds true both for firm size in terms of the number of employees as well as operating revenue and value added. The latter becomes clear from the difference in initial average labour productivity (measured as value added or operating revenue per employee) across beneficiary and non-beneficiary firms, which is not substantial relative to the one in the number of employees.

52. While treated firms appear to be initially more productive in terms of labour productivity, TFP (measured by the Solow residual) is higher for firms that are part of the control group. Furthermore, firms that receive co-funding from the structural funds or the Cohesion Fund have a higher mean capital-tolabour-ratio and are on average older but less liquid than the firms in the control group.

Table 10 shows a comparison for the mean of the outcome variables to be analysed in the subsequent section across the treatment and control group. The outcomes represent the change in the respective variable across the programming period 2007-2013 and it turns out, that e.g., supported firms that have started from lower initial values of TFP (see above) experienced higher TFP growth than those in the control group. However, note that these are unconditional values. A causal assessment of the impact of cohesion policy on firm-level performance is done in the next section.

\section{Results}

\section{Results on firms' employment, operating revenue (per employee) and total factor productivity}

53. Table 11 presents the estimation results on the impact of a firm carrying out a project on its number of employees, productivity and other firm characteristics. Differences are calculated between the respective values prior to the treatment (2007 if 2006 data is not available) and the period after the MFF (2014 or, if not available, 2015 or 2016). While the first outcome variable in Table 11 measures the change in the number of employees from 2006 (or 2007) to the period after the MFF 2007-2013 in absolute terms (net job creation), all other outcome variables are measured in log differences. Note that the total factor productivity (TFP) growth effects cannot be estimated for the Slovak Republic due to limited data coverage. 
Table 11. Average treatment effects on the treated (ATT) on a set of firm performance indicators and characteristics of individual beneficiaries

\begin{tabular}{|c|c|c|c|c|}
\hline Country & No. of obs. & No. of treated obs. & ATT & Bootstrapped S.E. \\
\hline & & & \multicolumn{2}{|c|}{ Change in absolute number of employees } \\
\hline ALL COUNTRIES & 126,252 & 17,416 & $5.81^{* \star}$ & 2.72 \\
\hline Czech Republic & 5470 & 1982 & 1141 & 980 \\
\hline Spain & 44,067 & 7,923 & 6.69 & 4.67 \\
\hline France & 11,171 & 400 & -31.70 & 77.30 \\
\hline Italy & 43,106 & 4,572 & $10.01^{* * *}$ & 2.74 \\
\hline Portugal & 19,825 & 2,149 & $5.85^{\star}$ & 3.20 \\
\hline \multirow[t]{2}{*}{ Slovak Republic } & 2,610 & 387 & $-38.06^{*}$ & 20.33 \\
\hline & & & \multicolumn{2}{|c|}{ Log change in operating revenue } \\
\hline ALL COUNTRIES & 191,574 & 20,275 & $0.02^{* * *}$ & 0.00 \\
\hline Czech Republic & 6,697 & 2,143 & $0.02^{* * *}$ & 0.00 \\
\hline Spain & 71,165 & 9,961 & $0.02^{* * *}$ & 0.00 \\
\hline France & 22,663 & 661 & $0.01^{* * *}$ & 0.00 \\
\hline Italy & 59,232 & 4,820 & $0.03^{* * *}$ & 0.00 \\
\hline Portugal & 28,862 & 2,294 & $0.02^{* * *}$ & 0.00 \\
\hline \multirow[t]{2}{*}{ Slovak Republic } & 2,952 & 393 & 0.02 & 0.01 \\
\hline & & & \multicolumn{2}{|c|}{$\begin{array}{c}\text { Log change in operating revenue per } \\
\text { employee }\end{array}$} \\
\hline ALL COUNTRIES & 125,976 & 17,405 & $-0.09^{* * *}$ & 0.01 \\
\hline Czech Republic & 5150 & & & \\
\hline $\begin{array}{l}\text { Czech Repubilc } \\
\text { Spain }\end{array}$ & 5,459 & 1,982 & $-0.14^{\star \star \star}$ & 0.03 \\
\hline Spain & 44,038 & 7,918 & $-0.10^{\star * *}$ & 0.02 \\
\hline France & 11,165 & 400 & $-0.11^{* *}$ & 0.04 \\
\hline Italy & 42,964 & 4,568 & $-0.05^{* *}$ & 0.02 \\
\hline Portugal & 19,767 & 2,146 & $-0.10^{\star \star \star}$ & 0.03 \\
\hline \multirow[t]{2}{*}{ Slovak Republic } & 2,579 & 387 & -0.05 & 0.08 \\
\hline & & & \multicolumn{2}{|c|}{$\begin{array}{l}\text { Total factor productivity growth (Solow } \\
\text { residual): Based on total fixed assets } \\
\text { (log change) }\end{array}$} \\
\hline ALL COUNTRIES & 92,131 & 12,339 & 0.02 & 0.02 \\
\hline Czech Republic & 2255 & 912 & 0.05 & 0.08 \\
\hline Spain & 24,254 & 4,599 & $0.06^{* *}$ & 0.03 \\
\hline France & 10,212 & 388 & 0.03 & 0.09 \\
\hline Italy & 38,312 & 4,370 & $0.05^{\star *}$ & 0.03 \\
\hline \multirow[t]{2}{*}{ Portugal } & 16,835 & 2,072 & $0.09^{* *}$ & 0.04 \\
\hline & & & \multicolumn{2}{|c|}{$\begin{array}{l}\text { Total factor productivity growth (Solow } \\
\text { residual): Based on tangible fixed assets } \\
\text { (log change) }\end{array}$} \\
\hline ALL COUNTRIES & 88,648 & 12,061 & $0.04^{* *}$ & 0.02 \\
\hline Czech Republic & 2,192 & 889 & 0.05 & 0.08 \\
\hline Spain & 23,180 & 4,501 & $0.06^{*}$ & 0.03 \\
\hline France & 9,426 & 362 & -0.06 & 0.10 \\
\hline Italy & 37,289 & 4,270 & 0.01 & 0.03 \\
\hline Portugal & 16,307 & 2,042 & $0.10^{* *}$ & 0.04 \\
\hline
\end{tabular}




\begin{tabular}{|c|c|c|c|c|}
\hline & & & \multicolumn{2}{|c|}{ Log change in fixed assets } \\
\hline ALL COUNTRIES & 118,101 & 17,981 & $0.30^{* * *}$ & 0.01 \\
\hline & & & & \\
\hline Czech Republic & 4,676 & 2,035 & $0.40^{* \star *}$ & 0.04 \\
\hline Spain & 42,691 & 8,237 & $0.28^{* * *}$ & 0.02 \\
\hline France & 10,547 & 553 & $0.31^{* * *}$ & 0.08 \\
\hline Italy & 40,513 & 4,603 & $0.23^{* * *}$ & 0.03 \\
\hline Portugal & 17,617 & 2,162 & $0.43^{* * *}$ & 0.04 \\
\hline \multirow[t]{2}{*}{ Slovak Republic } & 2,053 & 387 & $0.57^{* * *}$ & 0.10 \\
\hline & & & \multicolumn{2}{|c|}{ Log change in fixed assets per employee } \\
\hline ALL COUNTRIES & 117,190 & 17,356 & $0.11^{* * *}$ & 0.01 \\
\hline Czech Republic & 4,616 & 1,975 & $0.22^{\star * *}$ & 0.04 \\
\hline Spain & 42,338 & 7,884 & $0.07^{* * *}$ & 0.02 \\
\hline France & 10,360 & 400 & $0.12^{*}$ & 0.07 \\
\hline Italy & 40,219 & 4,561 & $0.09^{* * *}$ & 0.03 \\
\hline Portugal & 17,599 & 2,144 & $0.17^{* * *}$ & 0.04 \\
\hline \multirow[t]{3}{*}{ Slovak Republic } & 2,052 & 386 & $0.30^{* * *}$ & 0.10 \\
\hline & & & & \\
\hline & & & \multicolumn{2}{|c|}{$\begin{array}{l}\text { Log change in cost of employees per } \\
\text { operating revenue }\end{array}$} \\
\hline ALL COUNTRIES & 118,062 & 18,120 & $-0.12^{* * *}$ & 0.01 \\
\hline & & & & \\
\hline Czech Republic & 4,520 & 1,889 & $-0.11^{* * *}$ & 0.03 \\
\hline Spain & 43,309 & 8,707 & $-0.12^{* * *}$ & 0.02 \\
\hline France & 10,376 & 561 & $-0.14^{* * *}$ & 0.03 \\
\hline Italy & 40,109 & 4,618 & $-0.10^{* * *}$ & 0.02 \\
\hline Portugal & 17,693 & 1,968 & $-0.14^{* \star *}$ & 0.03 \\
\hline \multirow[t]{2}{*}{ Slovak Republic } & 2,053 & 375 & -0.04 & 0.07 \\
\hline & & & \multicolumn{2}{|c|}{$\begin{array}{l}\text { Log change in cost of employees per } \\
\text { employee }\end{array}$} \\
\hline ALL COUNTRIES & 115,963 & 16,273 & $-0.20^{* * *}$ & 0.01 \\
\hline & & & & \\
\hline Czech Republic & 4,426 & 1,797 & $-0.18^{* * *}$ & 0.04 \\
\hline Spain & 41,992 & 7,386 & $-0.22^{* * *}$ & 0.02 \\
\hline France & 10,141 & 357 & $-0.20^{* * *}$ & 0.06 \\
\hline Italy & 39,736 & 4,477 & $-0.18^{* * *}$ & 0.02 \\
\hline Portugal & 17,610 & 1,878 & $-0.25^{* * *}$ & 0.04 \\
\hline Slovak Republic & 2,052 & 372 & $-0.18^{*}$ & 0.10 \\
\hline
\end{tabular}

Notes: ${ }^{* * *}$ significant at the $1 \%$-level, ${ }^{* *}$ at $5^{*}$-level, ${ }^{*}$ at $10 \%$-level. All treated observations are on support. Standard errors are bootstrapped with 1,000 replications. Propensity scores are estimated using logit regression.

54. The estimated country-specific ATTs on the first outcome variable reveal the heterogeneity of policy effects across countries. Only treated firms located in Italy and Portugal could increase their number of employees between the pre-treatment and post-treatment period significantly more than without the funding assistance. Italian manufacturing firms that received co-funding, created approximately ten jobs more, Portuguese firms about six jobs more, than in the case of non-treatment. For firms located in the other countries, we do not find significant effects in the empirical analysis, while for firms in the Slovak Republic the ATT is negative and significant at the $10 \%$-level. This result may be driven by the relatively limited number of treated firms in the sample that is matched with ORBIS. 
55. Next, Table 11 shows that treated manufacturing firms' operating revenue, measured relative to their number of employees, grows by five to fourteen percentage points less across the MFF 2007-2013 than if the firms were not treated. This is true for the Czech Republic, Spain, France, Italy and Portugal, while the ATT for the Slovak Republic does not turn out to be significant. One explanation is based on the finding, as also reported in Table 11, that operating revenue in co-funded firms on average grows by 2 percentage points more than that of the control group in our sample. In Italy, where the policy-induced additional growth in operating revenues is highest, the labour productivity (operating revenue per employee) is smallest, whereas the growth effect is not statistically significant in the Slovak Republic. Furthermore, the results imply that employment growth over the period may have been higher than revenue growth in the majority of supported firms. ${ }^{19}$

56. Regarding total factor productivity growth, we find that there is a significant and positive impact only for firms that have received co-funding from the ERDF, ESF or the CF in Spain, Italy and Portugal. The statistically significant effect on TFP growth in treated manufacturing firms in Spain amounts to six percentage points more over the period of about nine years than without funding. Portuguese firms that carried out a co-funded project grew by nine to ten percentage points more in total factor productivity (independently of the measure used). For Italy, a positive and significant increase of TFP growth induced by cohesion policy is found only for one of the two TFP measures.

\section{Results on firms' fixed assets and labour compensation growth}

57. Moreover, Table 11 lists the estimation results on the development of manufacturing firms' fixed assets and fixed assets per employee as outcome variables. The first one may reflect the evolvement of the (tangible and intangible) capital stock and investment of the firm over the programming period. In both cases, we find that the variables in treated firms are positively affected by the treatment in all countries. Fixed assets growth turns out to be on average 37 percentage points higher in firms when they have carried out a project. For all of the six countries, estimation results also point to higher growth in terms of the treated firms' capital-labour-ratio (fixed assets per employee). As employment growth (in absolute terms) in treated firms is higher due to treatment, it is an intuitive result that capital-labour-ratio growth is lower than fixed assets growth in quantitative terms.

58. Finally, we examine how receiving co-funding from the ERDF, the ESF or CF influences the cost of employees, or labour compensation. As a robust result across countries, cost of employees appears to grow less in beneficiary firms than in case they would not have been treated. Relative to the number of employees, we find that the labour compensation in treated firms grows by 18 to 25 percentage points less across the analysed period. This can mean that wages grew slower or that the composition of employees shifted more towards low-wage workers. Measured as a share of operating revenue, the coefficients (ATTs) range from -0.10 to -0.14 and are not statistically significant in the Slovak Republic. One could assume that this is linked to the very small and mostly not significant TFP growth effect induced by carrying out a project.

\section{Comparison of firm-level effects of projects co-funded by the ERDF and the ESF}

59. In the next step, we aim at further investigating firm-level effects of carrying out projects cofunded by different funds. Therefore, the sample is extended to not only consist of one observation per treated firm (as it was the case for the previous analyses where it was just distinguished between treated

\footnotetext{
${ }^{19}$ Note that Bachtrögler et al. (2017a) find a small but positive and significant effect on value added per employee growth over this period, which, however, is not present in all countries in their sample.
} 
and non-treated firms) but potentially multiple ones if i) the same beneficiary receives co-funding from different funds or ii) carries out projects corresponding to different priority themes. ${ }^{20}$

60. By that, it is possible to estimate the effects of receiving financial assistance from the ERDF as compared to funds from the ESF (see Table 12). ${ }^{21}$ Due to data limitations, this analysis is possible for the Czech Republic, Spain, Italy and Portugal, and we only consider three outcome variables. Moreover, as the sample used in this section only consists of manufacturing firms, we are able to distinguish between projects co-funded by the ERDF (about 37,700 projects in total, if not excluding observations due to ORBIS data availability) and the ESF (approx. 9,000 projects). However, the analysis is not possible for the $\mathrm{CF}$ as the corresponding number of observations is very small (176 projects in total).

Table 12. Average treatment effects on the treated (ATT) considering multiple projects per beneficiary - Per funding instrument

\begin{tabular}{|c|c|c|c|c|c|}
\hline \multicolumn{2}{|l|}{ Country } & \multirow[t]{2}{*}{ No. of obs. } & \multirow[t]{2}{*}{$\begin{array}{l}\text { No. of } \\
\text { treated obs. }\end{array}$} & ATT & \multirow[t]{2}{*}{ Bootstrapped S.E. } \\
\hline & & & & Change in abs & \\
\hline \multirow[t]{2}{*}{ ALL COUNTRIES } & ERDF & 133,248 & 18,687 & $4.19^{* *}$ & 1.95 \\
\hline & ESF & 132,939 & 5,599 & 4.93 & 3.72 \\
\hline \multirow[t]{2}{*}{ Czech Republic } & ERDF & 5,846 & 1,670 & 4.65 & 8.52 \\
\hline & ESF & 5,846 & 431 & 6.85 & 29.51 \\
\hline \multirow[t]{2}{*}{ Spain } & ERDF & 48,839 & 10,497 & -0.250 & 3.11 \\
\hline & ESF & 48,837 & 2,205 & 1.19 & 3.01 \\
\hline \multirow[t]{2}{*}{ Italy } & ERDF & 44,073 & 4,228 & $12.20^{\star * *}$ & 3.40 \\
\hline & ESF & 44,079 & 1,285 & 3.74 & 5.57 \\
\hline \multirow[t]{3}{*}{ Portugal } & ERDF & 20,609 & 1,595 & $5.58^{*}$ & 3.29 \\
\hline & ESF & 20,608 & 1,533 & -1.50 & 3.43 \\
\hline & & & & \multicolumn{2}{|c|}{ Log change in operating revenue } \\
\hline \multirow[t]{2}{*}{ ALL COUNTRIES } & ERDF & 132,915 & 18,674 & $0.02^{* * *}$ & 0.00 \\
\hline & ESF & 132,606 & 5,595 & $0.01^{* * *}$ & 0.00 \\
\hline \multirow[t]{2}{*}{ Czech Republic } & ERDF & 5,834 & 1,670 & $0.01^{* * *}$ & 0.00 \\
\hline & ESF & 5,834 & 431 & 0.00 & 0.00 \\
\hline \multirow[t]{2}{*}{ Spain } & ERDF & 48,809 & 10,492 & $0.01^{* * *}$ & 0.00 \\
\hline & ESF & 48,807 & 2,204 & $0.01^{* *}$ & 0.00 \\
\hline \multirow[t]{2}{*}{ Italy } & ERDF & 43,910 & 4,222 & $0.02^{\star * *}$ & 0.00 \\
\hline & ESF & 43,916 & 1,284 & $0.01^{* * *}$ & 0.00 \\
\hline \multirow[t]{2}{*}{ Portugal } & ERDF & 20,534 & 1,593 & $0.02^{* * *}$ & 0.00 \\
\hline & ESF & 20,533 & 1,531 & $0.01^{* * *}$ & 0.00 \\
\hline
\end{tabular}

${ }^{20}$ Furthermore, it would have been interesting to assess potential differences in short-term versus medium-term effects. Unfortunately, managing authorities have reported project start and end dates only in very few countries or regions. As we lose further observations by ORBIS matching and data coverage such an analysis can only be performed for a set of projects carried out in the Czech Republic and Italy (not in all regions). In the difference-indifference estimation for projects that started before 2011, no (medium-term) policy effect is identified for manufacturing firms. However, given the limited data, we do not expect this result to have external validity.

${ }^{21}$ We cannot distinguish between projects co-funded by the ERDF and CF in many cases, thus, the analysis is limited to the ERDF and the ESF. 


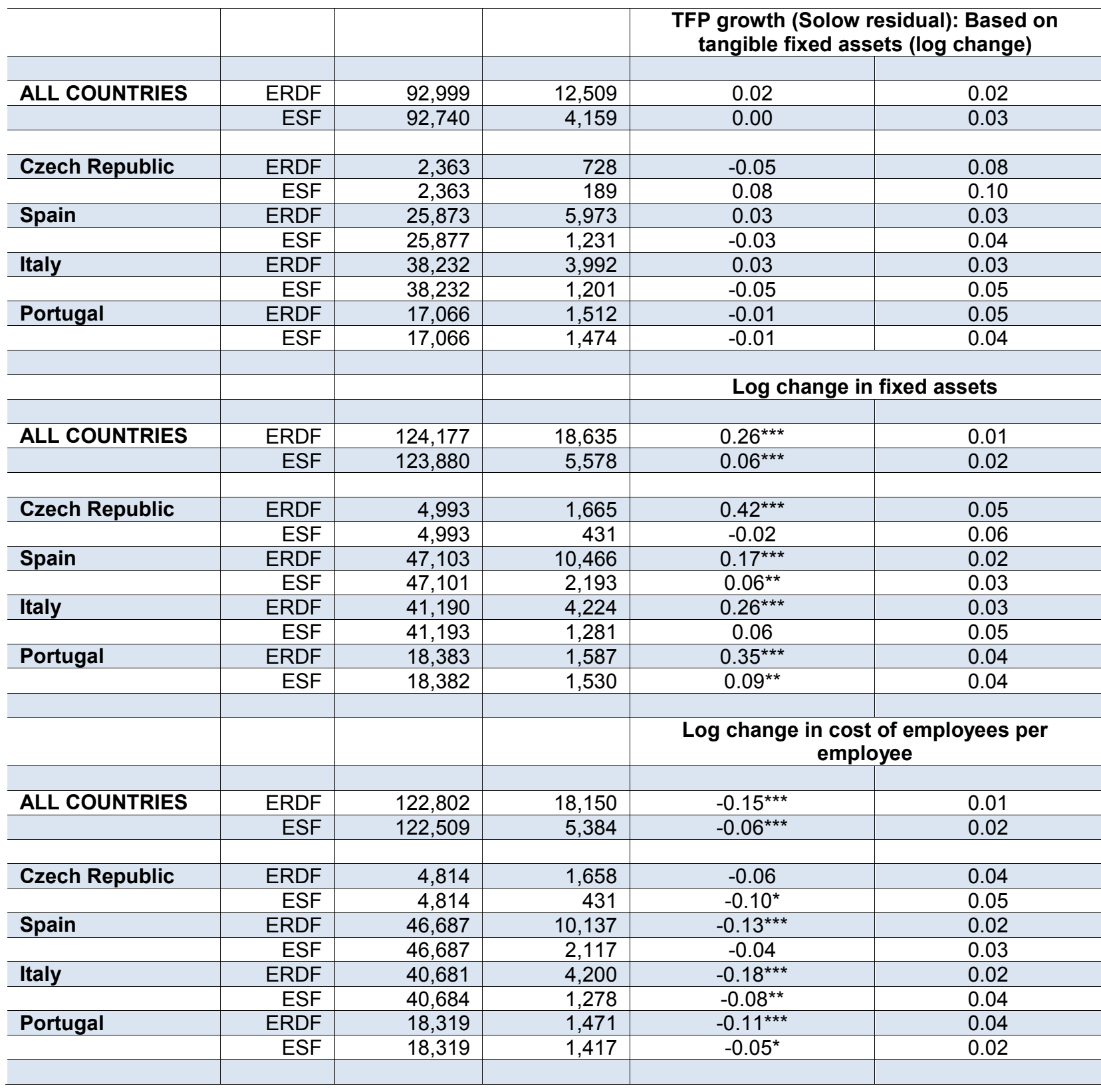

Notes: ${ }^{* * *}$ significant at the $1 \%$-level, ${ }^{* *}$ at $5^{*}$-level, ${ }^{*}$ at $10 \%-l e v e l$. All treated observations are on support. Standard errors are bootstrapped with 100 replications. Propensity scores are estimated using probit regression. Multiple projects by treated firm are considered when the particular firm carries out projects co-funded by different instruments (ERDF or ESF or CF) or corresponding to different priority themes. Projects with a project value below 820 Euro are excluded from the estimation.

61. The results in Table 12 show that, first, the significant impact of carrying out a project on firms' net job creation in Italy and Portugal appears to be driven by those projects that are co-funded by the ERDF (the size of the coefficients is also similar). In contrast, ESF-funded projects do not seem to affect firm employment. Likewise, the treatment effect of ERDF co-funded projects on fixed assets growth from 2007 (2006) to 2014 (or later) seems to be crucial for the overall impact in the Czech Republic and Italy. Contrarily, in Spain and Portugal, also projects co-funded by the ESF seem to contribute to the treated firms' additional growth in their capital stock. However, the corresponding coefficient is smaller. Finally, the impact on the cost of employees that turns out to be negative and significant for supported firms is weaker in projects co-funded by the ESF (except in the Czech Republic). As large parts of Human capital and Labour market projects are co-funded by the ESF (see Table 8), this is an expected result. 


\section{Comparison of firm-level effects of projects contributing to different priority themes}

62. Furthermore, our dataset enables us to differentiate between projects that contribute to different priority themes. We group the fifteen themes as defined by DG REGIO for the MFF 2007-2013 into five groups: Transportation infrastructure, Energy \& Environment, Tourism \& Social Infrastructure, Human Capital \& Labour Market (Human capital) and Business Services \& Urban Dimension (Business support) (refer to Bachtrögler et al. 2017b for details on the categorisation). Due to data limitations, it is possible to run separate difference-in-difference estimations (and the propensity score matching analysis) only for two of these groups, namely, Human capital $^{22}$ and Business support ${ }^{23}$.

63. Table 13 presents the results. With regard to the change in the absolute number of employees, the overall significant impact of carrying out a project on the treated firms in Italy does not seem to be driven by projects in the thematic categories analysed here. In contrast, for Portuguese manufacturing firms, the effect of carrying out a project in the Business support category, e.g. a research or innovation project, leads to the creation of 15 more jobs. The additional decline in labour compensation in supported firms is higher and significant in all countries in the case of Business support projects.

64. Turning to the other outcome variables, TFP growth in funded firms appears to be negatively affected by Business support projects in the Czech Republic and Spain, while Human capital projects show no significant impact in any country. The positive effect on the growth of fixed assets (as in the baseline results in Table 11 and 12) is found for firms carrying out Business support projects, however, not always with respect to Human capital projects.

Table 13. Average treatment effects on the treated (ATT) considering multiple projects per beneficiary - Per priority theme group

\begin{tabular}{|c|c|c|c|c|c|}
\hline \multicolumn{2}{|l|}{ Country } & \multirow[t]{2}{*}{$\begin{array}{l}\text { No. of } \\
\text { obs. }\end{array}$} & \multirow[t]{2}{*}{$\begin{array}{l}\text { No. of treated } \\
\text { obs. }\end{array}$} & ATT & \multirow{2}{*}{$\begin{array}{l}\text { Bootstrapped S.E } \\
\text { olute number of } \\
\text { loyees }\end{array}$} \\
\hline & & & & Change $\mathrm{i}$ & \\
\hline \multirow[t]{2}{*}{ ALL COUNTRIES } & Human cap. & 133,049 & 6,566 & 4.19 & 2.83 \\
\hline & Busi. supp. & 132,461 & 11,553 & $7.27^{\star \star \star}$ & 2.80 \\
\hline \multirow[t]{2}{*}{ Czech Republic } & Human cap. & 5,846 & 428 & 6.15 & 33.67 \\
\hline & Busi. supp. & 5,846 & 1,594 & 1.59 & 8.04 \\
\hline \multirow[t]{2}{*}{ Spain } & Human cap. & 48,837 & 3,104 & 0.00 & 1.98 \\
\hline & Busi. supp. & 48,828 & 5,645 & -0.24 & 2.42 \\
\hline \multirow[t]{2}{*}{ Italy } & Human cap. & 44,079 & 2,577 & 3.11 & 3.04 \\
\hline & Busi. supp. & 43,689 & 937 & 4.51 & 4.24 \\
\hline \multirow[t]{3}{*}{ Portugal } & Human cap. & 20,447 & 244 & -2.83 & 6.05 \\
\hline & Busi. supp. & 20,607 & 2,875 & $14.94^{\star * *}$ & 2.86 \\
\hline & & & & \multicolumn{2}{|c|}{ Log change in operating revenue } \\
\hline \multirow{2}{*}{ ALL COUNTRIES } & Human cap. & 132,716 & 6,560 & $0.01^{* * *}$ & 0.00 \\
\hline & Busi. supp. & 132,130 & 11,546 & $0.01^{* * *}$ & 0.00 \\
\hline \multirow[t]{2}{*}{ Czech Republic } & Human cap. & 5,834 & 428 & 0.00 & 0.00 \\
\hline & Busi. supp. & 5,834 & 1,594 & $0.02^{* * *}$ & 0.00 \\
\hline
\end{tabular}

\footnotetext{
${ }^{22}$ This category consists of the priority themes Human Capital, Labour Market and Social Inclusion. Refer to the appendix for a more detailed description.

23 This group summarizes the priority themes Innovation \& RTD, Other SME and Business Support, Capacity Building, and IT services and infrastructure. Refer to the appendix for a more detailed description.
} 


\begin{tabular}{|c|c|c|c|c|c|}
\hline Spain & Human cap. & 48,807 & 3,102 & $0.01^{\star * *}$ & 0.00 \\
\hline & Busi. supp. & 48,798 & 5,642 & $0.01^{* *}$ & 0.00 \\
\hline \multirow[t]{2}{*}{ Italy } & Human cap. & 43,916 & 2,573 & $0.01^{* * *}$ & 0.00 \\
\hline & Busi. supp. & 43,528 & 937 & 0.00 & 0.00 \\
\hline \multirow[t]{3}{*}{ Portugal } & Human cap. & 20,372 & 244 & 0.00 & 0.01 \\
\hline & Busi. supp. & 20,532 & 2,871 & $0.02^{* * *}$ & 0.00 \\
\hline & & & & \multicolumn{2}{|c|}{$\begin{array}{l}\text { Total factor productivity growth } \\
\text { (Solow residual): Based on tangible } \\
\text { fixed assets (log change) }\end{array}$} \\
\hline \multirow[t]{2}{*}{ ALL COUNTRIES } & Human cap. & 92,837 & 4,730 & $-0.05^{\star *}$ & 0.03 \\
\hline & Busi. supp. & 92,349 & 7,719 & 0.00 & 0.02 \\
\hline \multirow[t]{2}{*}{ Czech Republic } & Human cap. & 2,363 & 189 & 0.08 & 0.12 \\
\hline & Busi. supp. & 2,363 & 696 & $-0.16^{\star *}$ & 0.08 \\
\hline \multirow[t]{2}{*}{ Spain } & Human cap. & 25,878 & 1,743 & -0.02 & 0.03 \\
\hline & Busi. supp. & 25,873 & 3,228 & $-0.06^{* *}$ & 0.03 \\
\hline \multirow[t]{2}{*}{ Italy } & Human cap. & 38,232 & 2,435 & 0.02 & 0.03 \\
\hline & Busi. supp. & 37,909 & 888 & 0.00 & 0.05 \\
\hline \multirow[t]{3}{*}{ Portugal } & Human cap. & 16,927 & 237 & 0.00 & 0.09 \\
\hline & Busi. supp. & 17,066 & 2,742 & 0.05 & 0.05 \\
\hline & & & & \multicolumn{2}{|c|}{ Log change in fixed assets } \\
\hline \multirow[t]{2}{*}{ ALL COUNTRIES } & Human cap. & 123,999 & 6,541 & $0.09^{* * *}$ & 0.02 \\
\hline & Busi. supp. & 123,438 & 11,520 & $0.23^{* * *}$ & 0.01 \\
\hline \multirow{2}{*}{ Czech Republic } & Human cap. & 4,993 & 428 & -0.05 & 0.06 \\
\hline & Busi. supp. & 4,993 & 1,589 & $0.41^{* * *}$ & 0.04 \\
\hline \multirow[t]{2}{*}{ Spain } & Human cap. & 47,101 & 3,088 & 0.03 & 0.02 \\
\hline & Busi. supp. & 47,092 & 5,629 & $0.09^{* \star *}$ & 0.02 \\
\hline \multirow[t]{2}{*}{ Italy } & Human cap. & 41,193 & 2,570 & $0.16^{\star * *}$ & 0.03 \\
\hline & Busi. supp. & 40,833 & 937 & $0.13^{* * *}$ & 0.05 \\
\hline \multirow[t]{3}{*}{ Portugal } & Human cap. & 18,237 & 244 & 0.01 & 0.08 \\
\hline & Busi. supp. & 18,383 & 2,866 & $0.39^{* * *}$ & 0.04 \\
\hline & & & & \multicolumn{2}{|c|}{$\begin{array}{c}\text { Log change in cost of employees per } \\
\text { employee }\end{array}$} \\
\hline & & & & & \\
\hline \multirow[t]{2}{*}{ ALL COUNTRIES } & Human cap. & 122,628 & 6,430 & $-0.10^{* * *}$ & 0.02 \\
\hline & Busi. supp. & 122,082 & 11,091 & $-0.11^{* * *}$ & 0.01 \\
\hline \multirow[t]{2}{*}{ Czech Republic } & Human cap. & 4,814 & 428 & -0.03 & 0.06 \\
\hline & Busi. supp. & 4,814 & 1,582 & $-0.08^{* *}$ & 0.04 \\
\hline \multirow[t]{2}{*}{ Spain } & Human cap. & 46,687 & 2,996 & $-0.05^{* * *}$ & 0.02 \\
\hline & Busi. supp. & 46,678 & 5,440 & $-0.09^{* * *}$ & 0.02 \\
\hline \multirow[t]{2}{*}{ Italy } & Human cap. & 40,684 & 2,563 & $-0.11^{* * *}$ & 0.03 \\
\hline & Busi. supp. & 40,329 & 933 & $-0.10^{\star *}$ & 0.04 \\
\hline \multirow[t]{2}{*}{ Portugal } & Human cap. & 18,177 & 235 & -0.01 & 0.06 \\
\hline & Busi. supp. & 18,319 & 2,646 & $-0.21^{* * *}$ & 0.04 \\
\hline
\end{tabular}

Notes: ${ }^{* * *}$ significant at the $1 \%$-level, ${ }^{* *}$ at $5^{*}$-level, ${ }^{*}$ at $10 \%-l e v e l$. All treated observations are on support. Standard errors are bootstrapped with 100 replications. Propensity scores are estimated using probit regression. Projects with a project value below 820 Euro are excluded from the estimation.

Caveats of the analysis

65. There are a number of caveats that need to be taken into account when considering the results. First, the data collection process was done between 2015 and 2017 when managing authorities were still 
updating their lists of beneficiaries, so we do not have the final lists in all cases. Second, in a few cases, we cannot determine if the project values are commitments or payments (however, note that this does not bias the estimates of firm-level effectiveness) and project start and end dates are only reported in very few lists of beneficiaries. Third, the location of the firm is not always the location of the project. However, we expect that the project in the majority of cases was carried out in the same region as the firm is located.

66. The matching process with ORBIS reduces the sample of firms to about a third of the overall observations, which is still more than 300,000 observations. A match does not mean that we have information on all variables.

67. In the firm-level analysis, we use propensity score matching in order to find non-treated firms that are similar to the treated firms. One assumption that we have to make is that both treated and nontreated firms did not receive similar public, non-EU co-funding ${ }^{24}$ or, put differently, that treated and untreated firms are (ex-ante) face the same probability of receiving similar, non-EU co-funding. Furthermore, one should keep in mind that the period under consideration overlaps with the Great Recession, which might influence the results.

\section{Robustness checks}

68. In order to check the robustness of the estimation results presented in the previous section we do not only consider a NUTS-2 fixed effect but also include a fixed effect for the NACE Rev. 2 1-digit level. This analysis is not possible at the country-level or using the NACE 4-2-digit code as the number of observations per category drops significantly. Table 14 shows the results.

Table 14. Robustness check: Average treatment effects on the treated (ATT) considering individual beneficiaries: Including the NACE Rev. 2-1 digit code

\begin{tabular}{|c|c|c|c|c|}
\hline Country & $\begin{array}{l}\text { No. of } \\
\text { obs. }\end{array}$ & $\begin{array}{l}\text { No. of treated } \\
\text { obs. }\end{array}$ & ATT & Bootstrapped S.E. \\
\hline & & & \multicolumn{2}{|c|}{ Change in absolute number of employees } \\
\hline \multirow[t]{2}{*}{ ALL COUNTRIES } & 126,252 & 17,416 & $5.00^{*}$ & 2.96 \\
\hline & & & \multicolumn{2}{|c|}{ Log change in operating revenue } \\
\hline \multirow[t]{2}{*}{ ALL COUNTRIES } & 125,933 & 17,404 & $0.02^{* \star *}$ & 0.00 \\
\hline & & & \multicolumn{2}{|c|}{$\begin{array}{c}\text { Log change in operating revenue per } \\
\text { employee }\end{array}$} \\
\hline \multirow[t]{2}{*}{ ALL COUNTRIES } & 125,975 & 17,404 & $-0.08^{* * *}$ & 0.01 \\
\hline & & & \multicolumn{2}{|c|}{$\begin{array}{l}\text { Total factor productivity growth (Solow } \\
\text { residual): Based on total fixed assets } \\
\text { (log change) }\end{array}$} \\
\hline \multirow[t]{2}{*}{ ALL COUNTRIES } & 91,868 & 12,341 & $0.03^{*}$ & 0.02 \\
\hline & & & \multicolumn{2}{|c|}{$\begin{array}{l}\text { Total factor productivity growth (Solow } \\
\text { residual): Based on tangible fixed assets } \\
\text { (log change) }\end{array}$} \\
\hline \multirow[t]{2}{*}{ ALL COUNTRIES } & 88,396 & 12,066 & $0.04^{* *}$ & 0.02 \\
\hline & & & \multicolumn{2}{|c|}{ Log change in fixed assets } \\
\hline ALL COUNTRIES & 117,189 & 17,355 & $0.32^{* \star *}$ & 0.01 \\
\hline
\end{tabular}

\footnotetext{
${ }^{24}$ If only the control group did, that would lead to underestimating the effectiveness of cohesion policy in this study.
} 


\begin{tabular}{|c|c|c|c|c|}
\hline \multirow[b]{2}{*}{ ALL COUNTRIES } & \multirow[b]{2}{*}{117,189} & \multirow[b]{2}{*}{17,355} & \multicolumn{2}{|c|}{ Log change in fixed assets per employee } \\
\hline & & & $0.12^{* * *}$ & 0.01 \\
\hline & & & \multicolumn{2}{|c|}{$\begin{array}{c}\text { Log change in cost of employees per } \\
\text { operating revenue }\end{array}$} \\
\hline \multirow[t]{2}{*}{ ALL COUNTRIES } & 115,915 & 16,268 & $-0.12^{\star \star \star}$ & 0.01 \\
\hline & & & \multicolumn{2}{|c|}{$\begin{array}{c}\text { Log change in cost of employees per } \\
\text { employee }\end{array}$} \\
\hline ALL COUNTRIES & 116,235 & 16,268 & $-0.20^{\star \star \star}$ & 0.01 \\
\hline
\end{tabular}

Notes: ${ }^{* * *}$ significant at the $1 \%$-level, ${ }^{* *}$ at $5^{*}$-level, ${ }^{*}$ at $10 \%$-level. All treated observations listed are on support. Standard errors are bootstrapped with 500 observations.

69. Moreover, taking into consideration the sum of project volumes per treated firm, we run the difference-in-difference analysis based on estimated propensity scores for the sample after excluding the smallest projects (see Table 15). ${ }^{25}$ This means, firms that carry out projects with a total volume below the $5^{\text {th }}$ percentile of the distribution (2,020.49 Euros), are dropped from the estimation sample. Most of them are located in Spain, Italy and Portugal, which is the reason for the only slightly reduced number of treated observations in the Czech Republic and France.

70. An interesting finding of this consistency check (Table 15) is that the number of jobs created over the programming period rises when excluding the projects with smallest project values. This intuitive result holds true for all countries except France and the overall ATT. The estimated ATTs on TFP growth of supported firms are not fully consistent with previously presented ones for the whole sample.

71. Finally, as small firms are underrepresented in ORBIS, we run the estimations when only considering firms that have less employees than the firm with the median employment value (taking both supported firms as well as the control group into account), that are less productive than the firm with median productivity and younger than the older half of firms in our sample. ${ }^{26}$ This helps shedding light on whether the segment of firms that we do not observe in ORBIS (typically the smaller, younger and less productive firms) might respond differently than the other segments.

72. The overall results considering all countries (analogous to the number of treated observations in the full sample, most of the firms are located in Spain, Portugal and Italy) show a similar picture as the estimation outcomes reported previously in this study. To be more precise, there is a positive and significant impact on absolute employment change, growth in operating revenues (however there is no significant ATT on operating revenues per employee), total factor productivity based on tangible fixed assets, fixed assets and the capital-labour-ratio (fixed assets per employees), and a negative and statistically significant on labour compensation. As one could expect, the absolute increase in the number of employees is smaller when taking into account only small firms (plus 1.19 employees), while the outcomes are higher for this reduced sample. To name one example, operating revenues grow by 4 percentage points more over the programming period 2007-2013 than those of firms that have not carried out co-funded projects.

\footnotetext{
${ }^{25}$ As indicated in the previous sections, the number of observations is still higher than in Table 11 as multiple projects per treated firm are considered when they are co-funded by different funding instruments or correspond to different priority themes.

${ }^{26}$ The median number of employees in the whole sample is seven, the value added per employee amounts to 3.59 and the median age is 11 years.
} 
Table 15. Robustness check: Average treatment effects on the treated (ATT) considering multiple projects per beneficiary but excluding the smallest projects

\begin{tabular}{|c|c|c|c|c|}
\hline Country & No. of obs. & $\begin{array}{l}\text { No. of treated } \\
\text { obs. }\end{array}$ & ATT & Bootstrapped S.E. \\
\hline & & & \multicolumn{2}{|c|}{ Change in absolute number of employees } \\
\hline ALL COUNTRIES & 132,029 & 23,138 & $8.79^{* * *}$ & 2.97 \\
\hline Czech Republic & 5,842 & 2,353 & $31.00^{* *}$ & 12.09 \\
\hline Spain & 47,695 & 11,509 & $13.37^{* *}$ & 6.48 \\
\hline France & 11,208 & 436 & -37.42 & 74.02 \\
\hline Italy & 44,025 & 5,469 & $14.72^{\star * *}$ & 2.98 \\
\hline Portugal & 20,587 & 2,925 & $11.48^{* * *}$ & 3.53 \\
\hline \multirow[t]{2}{*}{ Slovak Republic } & 2,662 & 436 & 18.11 & 21.02 \\
\hline & & & \multicolumn{2}{|c|}{ Log change in operating revenue } \\
\hline ALL COUNTRIES & 131,697 & 23,122 & $0.02^{* * *}$ & 0.00 \\
\hline & & & & \\
\hline Czech Republic & 5,830 & 2,353 & $0.02^{* * *}$ & 0.00 \\
\hline Spain & 47,666 & 11,504 & $0.02^{* * *}$ & 0.00 \\
\hline France & 11,197 & 436 & $0.01^{* * *}$ & 0.02 \\
\hline Italy & 43,862 & 5,462 & $0.02^{* \star *}$ & 0.00 \\
\hline Portugal & 20,510 & 2,919 & $0.03^{* * *}$ & 0.00 \\
\hline \multirow[t]{2}{*}{ Slovak Republic } & 2,620 & 436 & $0.05^{* * *}$ & 0.01 \\
\hline & & & \multicolumn{2}{|c|}{$\begin{array}{c}\text { Log change in operating revenue per } \\
\text { employee }\end{array}$} \\
\hline ALL COUNTRIES & 131,739 & 23,122 & $-0.11^{* * *}$ & 0.01 \\
\hline & & & & \\
\hline Czech Republic & 5,831 & 2,353 & -0.05 & 0.03 \\
\hline Spain & 47,673 & 11,504 & $-0.15^{* * *}$ & 0.02 \\
\hline France & 11,197 & 436 & $-0.09^{* *}$ & 0.04 \\
\hline Italy & 43,880 & 5,462 & $-0.12^{* * *}$ & 0.02 \\
\hline Portugal & 20,522 & 2,919 & $-0.16^{\star * *}$ & 0.03 \\
\hline \multirow[t]{2}{*}{ Slovak Republic } & 2,624 & 436 & 0.09 & 0.08 \\
\hline & & & \multicolumn{2}{|c|}{$\begin{array}{c}\text { Total factor productivity growth (Solow } \\
\text { residual): Based on total fixed assets } \\
\text { (log change) }\end{array}$} \\
\hline ALL COUNTRIES & 95,866 & 16,218 & $0.06^{* * *}$ & 0.02 \\
\hline Czech Republic & 2,431 & 1,043 & 0.08 & 0.07 \\
\hline Spain & 26,374 & 6,650 & $0.08^{\star \star}$ & 0.03 \\
\hline France & 10,246 & 422 & -0.08 & 0.10 \\
\hline Italy & 39,223 & 5,260 & 0.04 & 0.03 \\
\hline \multirow[t]{2}{*}{ Portugal } & 17,576 & 2,827 & $0.10^{* *}$ & 0.05 \\
\hline & & & \multicolumn{2}{|c|}{$\begin{array}{l}\text { Total factor productivity growth (Solow } \\
\text { residual): Based on tangible fixed assets } \\
\text { (log change) }\end{array}$} \\
\hline ALL COUNTRIES & 92,286 & 15,892 & 0.01 & 0.02 \\
\hline Czech Republic & 2,355 & 1,018 & -0.05 & 0.08 \\
\hline Spain & 25,231 & 6,529 & 0.05 & 0.04 \\
\hline France & 9,459 & 395 & 0.04 & 0.10 \\
\hline Italy & 38,184 & 5,144 & $0.10^{* * *}$ & 0.03 \\
\hline Portugal & 17,039 & 2,788 & 0.06 & 0.05 \\
\hline
\end{tabular}




\begin{tabular}{|c|c|c|c|c|}
\hline & & & \multicolumn{2}{|c|}{ Log change in fixed assets } \\
\hline ALL COUNTRIES & 122,963 & 23,074 & $0.34^{* * *}$ & 0.01 \\
\hline Czech Republic & 4,989 & 2,347 & $036^{* * *}$ & 0.05 \\
\hline Spain & 45,964 & 11,466 & $0.33^{\star \star \star}$ & 0.02 \\
\hline France & 10,396 & 435 & $0.39^{* * *}$ & 0.07 \\
\hline Italy & 41,139 & 5,460 & $0.27^{* \star *}$ & 0.03 \\
\hline Portugal & 18,361 & 2,920 & $0.41^{* * *}$ & 0.04 \\
\hline \multirow[t]{2}{*}{ Slovak Republic } & 2,103 & 435 & $0.55^{\star \star \star}$ & 0.09 \\
\hline & & & \multicolumn{2}{|c|}{ Log change in fixed assets per employee } \\
\hline ALL COUNTRIES & 122,963 & 23,074 & $0.11^{* * *}$ & 0.01 \\
\hline Czech Republic & 4,989 & 2,347 & $0.22^{\star * *}$ & 0.04 \\
\hline Spain & 45,964 & 11,466 & $0.06^{* * *}$ & 0.02 \\
\hline France & 10,396 & 435 & $0.21^{* * *}$ & 0.07 \\
\hline Italy & 41,139 & 5,460 & $0.09^{* * *}$ & 0.03 \\
\hline Portugal & 18,361 & 2,920 & $0.18^{* * *}$ & 0.04 \\
\hline \multirow[t]{2}{*}{ Slovak Republic } & 2,103 & 435 & $0.33^{\star * *}$ & 0.10 \\
\hline & & & \multicolumn{2}{|c|}{$\begin{array}{l}\text { Log change in cost of employees per } \\
\text { operating revenue }\end{array}$} \\
\hline ALL COUNTRIES & 121,571 & 21,892 & $-0.12^{* * *}$ & 0.01 \\
\hline & & & & \\
\hline $\begin{array}{l}\text { Czech Republic } \\
\text { Spain }\end{array}$ & $\begin{array}{r}4,808 \\
45,576\end{array}$ & $\begin{array}{r}2,1 / 1 \\
10,934\end{array}$ & $\frac{-0.05}{-0.16^{* * *}}$ & $\begin{array}{l}0.03 \\
0.02\end{array}$ \\
\hline France & 10,189 & 389 & -0.07 & 0.04 \\
\hline Italy & 40,610 & 5,366 & $-0.07^{* * *}$ & 0.02 \\
\hline Portugal & 18,277 & 2,597 & $-0.14^{* * *}$ & 0.03 \\
\hline \multirow[t]{2}{*}{ Slovak Republic } & 2,096 & 420 & $-0.19^{* * *}$ & 0.07 \\
\hline & & & \multicolumn{2}{|c|}{$\begin{array}{c}\text { Log change in cost of employees per } \\
\text { employee }\end{array}$} \\
\hline ALL COUNTRIES & 121,629 & 21,901 & $-0.21^{* \star *}$ & 0.01 \\
\hline & & & & \\
\hline Czech Republic & 4,810 & 2,171 & $-0.14^{* \star \star}$ & 0.05 \\
\hline Spain & 45,589 & 10,939 & $-0.28^{* * *}$ & 0.02 \\
\hline France & 10,192 & 389 & $-0.18^{* * *}$ & 0.07 \\
\hline Italy & 40,631 & 5,370 & $-0.16^{\star * *}$ & 0.02 \\
\hline Portugal & 18,294 & 2,597 & $-0.23^{\star * *}$ & 0.04 \\
\hline Slovak Republic & 2,098 & 420 & -0.03 & 0.10 \\
\hline
\end{tabular}

Notes: ${ }^{* * *}$ significant at the $1 \%$-level, ${ }^{* *}$ at $5^{*}$-level, ${ }^{*}$ at $10 \%$-level. All treated observations are on support. Standard errors are bootstrapped with 500 replications. Propensity scores are estimated using logit regression.

\section{Conclusion}

73. This paper contributes to a recently upcoming stream of literature on the firm-level dimension of EU cohesion policy evaluation. First, it presents a database that contains information on over 2,000,000 projects that were co-funded by the ERDF, the ESF or the CF during the MFF 2007-2013. The corresponding beneficiary firms or institutions are matched with the ORBIS database, which enables a more detailed analysis of the allocation of EU funds within European regions than has been possible so far. 
74. Descriptive statistics show that beneficiaries of Cohesion policy are a non-homogenous group. The absolute number of firms and projects differs widely. For instance, while the UK carried out around 5,500 projects, Spain (UK's GDP is twice as large) had over 650,000 projects. The average firm differs across countries in terms of size, turnover, capital intensity and other characteristics. The analysis also shows that there is variation in the thematic focus of the different funds. We see that the Cohesion Fund on the one hand co-finances larger projects, carried out by larger, more capital-intensive firms that carry out, among other things, infrastructure projects. On the other hand, the European Social Fund co-finances smaller projects related to Human Capital and initiatives on the labour market. However, in terms of volume, the European Regional and Development Fund has the largest budget in total.

75. Estimating causal effects (ATT) of carrying out a co-funded regional policy projects on a set of firm performance indicators and characteristics for manufacturing firms in six OECD countries shows that, indeed, receiving funding from the structural and cohesion funds makes a difference. We find that beneficiary firms in Italy and Portugal create more jobs and, in general, firms experience more growth in their operating revenue, fixed assets and capital-to-labour-ratio than if they would not have received support. Estimation results show significant TFP growth effects in Spain and Portugal. Moreover, costs of employees seem to grow less in beneficiary firms. This could mean that wages grew less or that beneficiary firms shifted more towards low-wage workers than non-beneficiaries did.

76. Taking into account characteristics of the projects carried out by manufacturing firms in four countries leads to some interesting findings. Net job creation effects in Italy and Portugal appear to be driven by projects co-funded by the ERDF (and not the ESF). Likewise, those projects contribute to the overall impact on fixed assets growth, whereby ESF co-funding also seems to have a positive effect on this outcome variable on treated firms in Spain and Portugal. Innovation \& RTD and other business projects appear to contribute to the additional (positive) change induced by the financial assistance through Cohesion Policy on net job creation in Portugal and on the growth of the capital stock (fixed assets) in the Czech Republic, Spain, Italy and Portugal. However, innovation and business projects also seem to be linked to negative TFP growth in treated firms in the Czech Republic and Spain.

77. These results show that positive effects seem to be rather specific. This needs to be investigated in future research, such as the fact that there is a lack of additional TFP growth in some countries despite capital deepening and a decrease in cost of employees in every country under consideration. 
ECO/WKP(2018)47

\section{APPENDIX}

\section{Construction and cleaning of the dataset}

78. In order to construct the database used in the analysis, information is collected from many sources. The main body of information on the co-funded projects originates from list of beneficiaries (LoB) that have to be reported by the national or regional managing authorities of operational programmes since 2007. In many cases, the lists refer to a specific operational programme, i.e. they cover a specific region and objective. Our database contains projects from 301 operational programmes. Those lists contain different amounts of information since there seems to be no standardisation process. Almost all lists are published in national language and in different formats (Word, Excel, PDF, Html). Furthermore, to the best of our knowledge, Hungary did not report any lists at the time of data collection. Additionally, the modest project funding did not allow us to translate the Greek and Cypriote lists of beneficiaries.

79. Once all lists are collected and brought into a common format, headers as well as project descriptions and project titles have to be translated into English. The resulting database is then merged with the BvD ORBIS business database. We use the ORBIS online matching tool that allows 1,000 company names in each matching step. In the end we could match beneficiaries of about a third of all projects, resulting in the coverage shown in Table 1 and Table 2. The matching procedure by ORBIS delivers suggestions for a match that are rated. We only accepted "A" matches and checked manually with "B" matches while all others were disregarded.

80. Further steps include the use of different exchange rates in order to convert all values in Euros since many project values are reported in local currency. All values in the database are denoted in Euros. Since we do not have information on the exact time payments to projects were made for the vast majority of observations, figures relating to the project value de facto represent a cross section, not time series. This means that there is no possibility of deflating the project payments.

\section{Imputation of project themes}

81. The thematic category of a project ("theme") is an interesting variable and important for the analysis since it is a way to label the content of the project, i.e. if it relates to infrastructure or human capital for instance. Unfortunately, it is often missing from the lists of beneficiaries. In order to improve the coverage of this variable, machine-learning techniques are employed to impute this data as far as possible. In a nutshell, an algorithm uses a sample of data that consists of a project description (in English) and one of fifteen thematic categories to learn how the categorisation can be done. The algorithm then uses project descriptions of projects where no theme is assigned, to find the appropriate thematic category. Thus, the algorithm can assign one of fifteen themes to a project based on the English description of the respective project. For this, all project descriptions are translated to English using the Google Translate API. For a detailed description of this method see (Bachtrögler et al., 2017b). In order to increase the transparency and reproducibility of the approach, there is a publicly available R package (fastTextR) that contains the code and the data (project description and theme label). The 15 themes (and corresponding more detailed categories) are: 
ECO/WKP(2018)47

\begin{tabular}{|c|c|}
\hline Priority Themes & Category \\
\hline \multirow[t]{8}{*}{ Innovation \& RTD } & R\&TD activities in research centres \\
\hline & R\&TD infrastructure and centres of competence in a specific technology \\
\hline & Technology transfer and improvement of cooperation networks ... \\
\hline & Assistance to R\&TD, particularly in SMEs (including access to R\&TD services in research centres) \\
\hline & $\begin{array}{l}\text { Assistance to SMEs for the promotion of environmentally-friendly products and production } \\
\text { processes (...) }\end{array}$ \\
\hline & Investment in firms directly linked to research and innovation (...) \\
\hline & Other measures to stimulate research and innovation and entrepreneurship in SMEs \\
\hline & $\begin{array}{l}\text { Developing human potential in the field of research and innovation, in particular through post- } \\
\text { graduate studies ... }\end{array}$ \\
\hline \multirow{6}{*}{$\begin{array}{l}\text { IT services and } \\
\text { infrastructure }\end{array}$} & Telephone infrastructures (including broadband networks) \\
\hline & Information and communication technologies (...) \\
\hline & Information and communication technologies (TEN-ICT) \\
\hline & Services and applications for citizens (e-health, e-government, e-learning, e-inclusion, etc.) \\
\hline & Services and applications for SMEs (e-commerce, education and training, networking, etc.) \\
\hline & Other measures for improving access to and efficient use of ICT by SMEs \\
\hline \multirow{3}{*}{$\begin{array}{l}\text { Other SME and Business } \\
\text { support }\end{array}$} & Advanced support services for firms and groups of firms \\
\hline & Other investment in firms \\
\hline & Support for self-employment and business start-up \\
\hline \multirow[t]{11}{*}{ Energy } & Electricity \\
\hline & Electricity (TEN-E) \\
\hline & Natural gas \\
\hline & Natural gas (TEN-E) \\
\hline & Petroleum products \\
\hline & Petroleum products (TEN-E) \\
\hline & Renewable energy: wind \\
\hline & Renewable energy: solar \\
\hline & Renewable energy: biomass \\
\hline & Renewable energy: hydroelectric, geothermal and other \\
\hline & Energy efficiency, co-generation, energy management \\
\hline \multirow[t]{12}{*}{ Environment } & Management of household and industrial waste \\
\hline & Management and distribution of water (drink water) \\
\hline & Water treatment (waste water) \\
\hline & Air quality \\
\hline & Integrated prevention and pollution control \\
\hline & Mitigation and adaption to climate change \\
\hline & Rehabilitation of industrial sites and contaminated land \\
\hline & Promotion of biodiversity and nature protection (including Natura 2000) \\
\hline & Risk prevention (...) \\
\hline & Other measures to preserve the environment and prevent risks \\
\hline & Promotion of natural assets \\
\hline & Protection and development of natural heritage \\
\hline
\end{tabular}


ECO/WKP(2018)47

\begin{tabular}{|c|c|}
\hline \multirow{5}{*}{$\begin{array}{l}\text { Culture, heritage and } \\
\text { tourism }\end{array}$} & Cycle tracks \\
\hline & Other assistance to improve tourist services \\
\hline & Protection and preservation of the cultural heritage \\
\hline & Development of cultural infrastructure \\
\hline & Other assistance to improve cultural services \\
\hline \multirow{4}{*}{$\begin{array}{l}\text { Urban and territorial } \\
\text { dimension }\end{array}$} & Integrated projects for urban and rural regeneration \\
\hline & Compensation of any additional costs due to accessibility deficit and territorial fragmentation \\
\hline & Specific action addressed to compensate additional costs due to size market factors \\
\hline & Support to compensate additional costs due to climate conditions and relief difficulties \\
\hline \multirow[t]{4}{*}{ Rail } & Railways \\
\hline & Railways (TEN-T) \\
\hline & Mobile rail assets \\
\hline & Mobile rail assets (TEN-T) \\
\hline \multirow[t]{4}{*}{ Road } & Motorways \\
\hline & Motorways (TEN-T) \\
\hline & National roads \\
\hline & Regional/local roads \\
\hline \multirow[t]{9}{*}{ Other transport } & Urban transport \\
\hline & Multimodal transport \\
\hline & Multimodal transport (TEN-T) \\
\hline & Intelligent transport systems \\
\hline & Airports \\
\hline & Ports \\
\hline & Inland waterways (regional and local) \\
\hline & Inland waterways (TEN-T) \\
\hline & Promotion of clean urban transport \\
\hline \multirow[t]{6}{*}{ Labour market } & Design and dissemination of innovative and more productive ways of organising work \\
\hline & $\begin{array}{l}\text { Development of special services for employment, training and support in connection with } \\
\text { restructuring of sectors... }\end{array}$ \\
\hline & Modernisation and strengthening labour market institutions \\
\hline & Implementing active and preventive measures on the labour market \\
\hline & Measures encouraging active ageing and prolonging working lives \\
\hline & $\begin{array}{l}\text { Measures to improve access to employment and increase sustainable participation and } \\
\text { progress of women ... }\end{array}$ \\
\hline \multirow[t]{2}{*}{ Social Inclusion } & Specific action to increase migrants' participation in employment ... \\
\hline & Pathways to integration and re-entry into employment for disadvantaged people ... \\
\hline \multirow[t]{5}{*}{ Social infrastructure } & Education infrastructure \\
\hline & Health infrastructure \\
\hline & Childcare infrastructure \\
\hline & Housing infrastructure \\
\hline & Other social infrastructure \\
\hline
\end{tabular}


ECO/WKP(2018)47

\begin{tabular}{|l|l|}
\hline Human capital & $\begin{array}{l}\text { Development of life-long learning systems and strategies in firms; training and services for } \\
\text { employees ... }\end{array}$ \\
\hline $\begin{array}{l}\text { Design, introduction and implementing of reforms in education and training systems ... } \\
\text { Capacity Building }\end{array}$ & $\begin{array}{l}\text { Measures to increase participation in education and training throughut the life-cycle ... } \\
\text { stakeholders } \\
\text { Mechanisms for improving good policy and programme design, monitoring and evaluation ... }\end{array}$ \\
\hline \begin{tabular}{l} 
Preparation, implementation, monitoring and inspection \\
\hline Evaluation and studies; information and communication
\end{tabular} \\
\hline
\end{tabular}

\section{Distribution by fund}

82. The following figures $6-9$ paint a clear picture and act as additional plausibility check for the data. In the following boxplots, the bold horizontal line represents the median and all values refer to single projects or firms. The Cohesion Fund co-finances the largest projects and firms with the most assets, most employees and the highest capital-to-labour ratio. The opposite is true for the European Social Fund. It's projects are relatively smallest and carried out by small relatively labour intensive firms. The ERDF is in between the other two.

Figure 6. Distribution of total values by type of fund

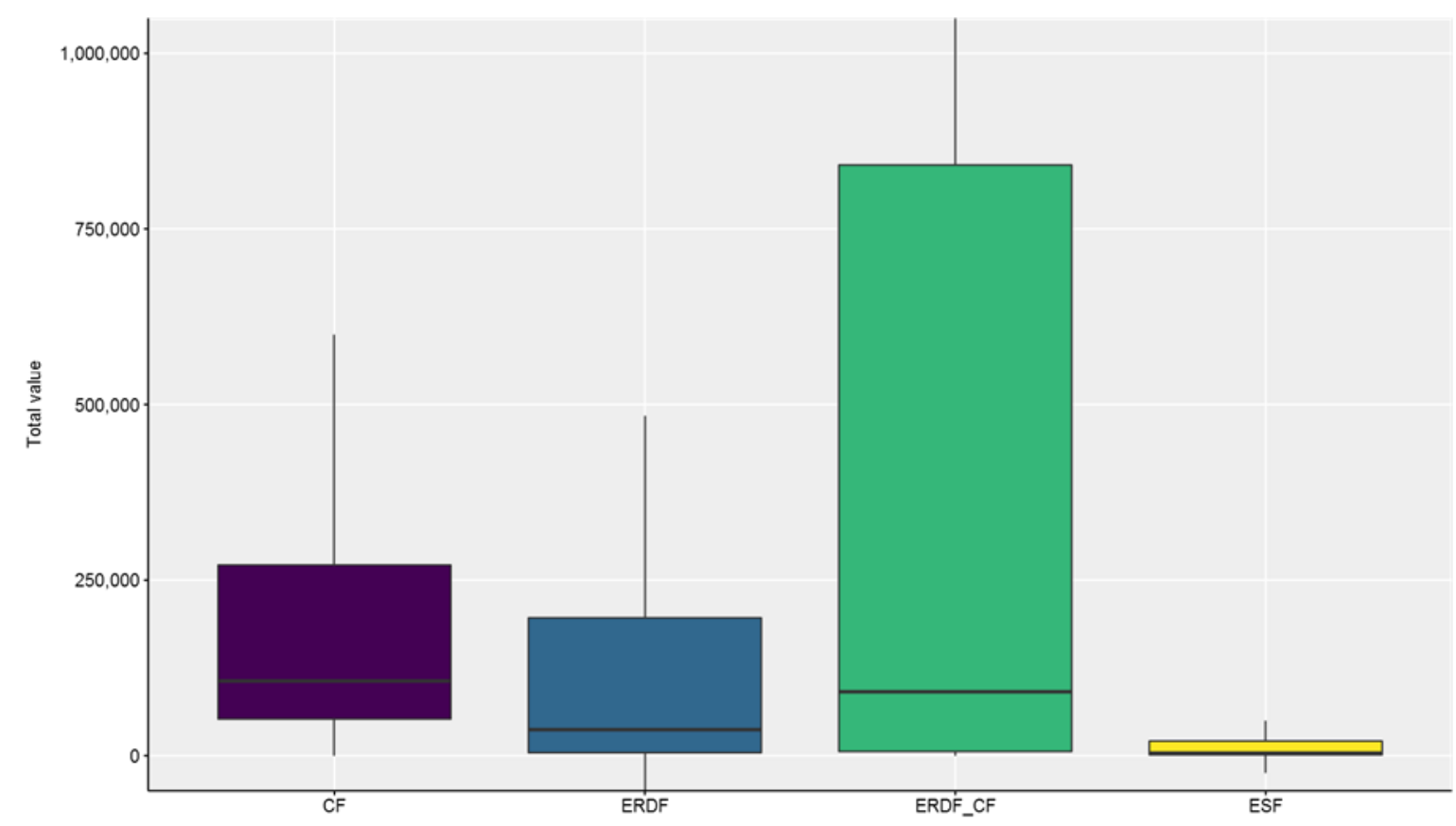


Figure 7. Distribution of firms' amount of total assets by type of fund

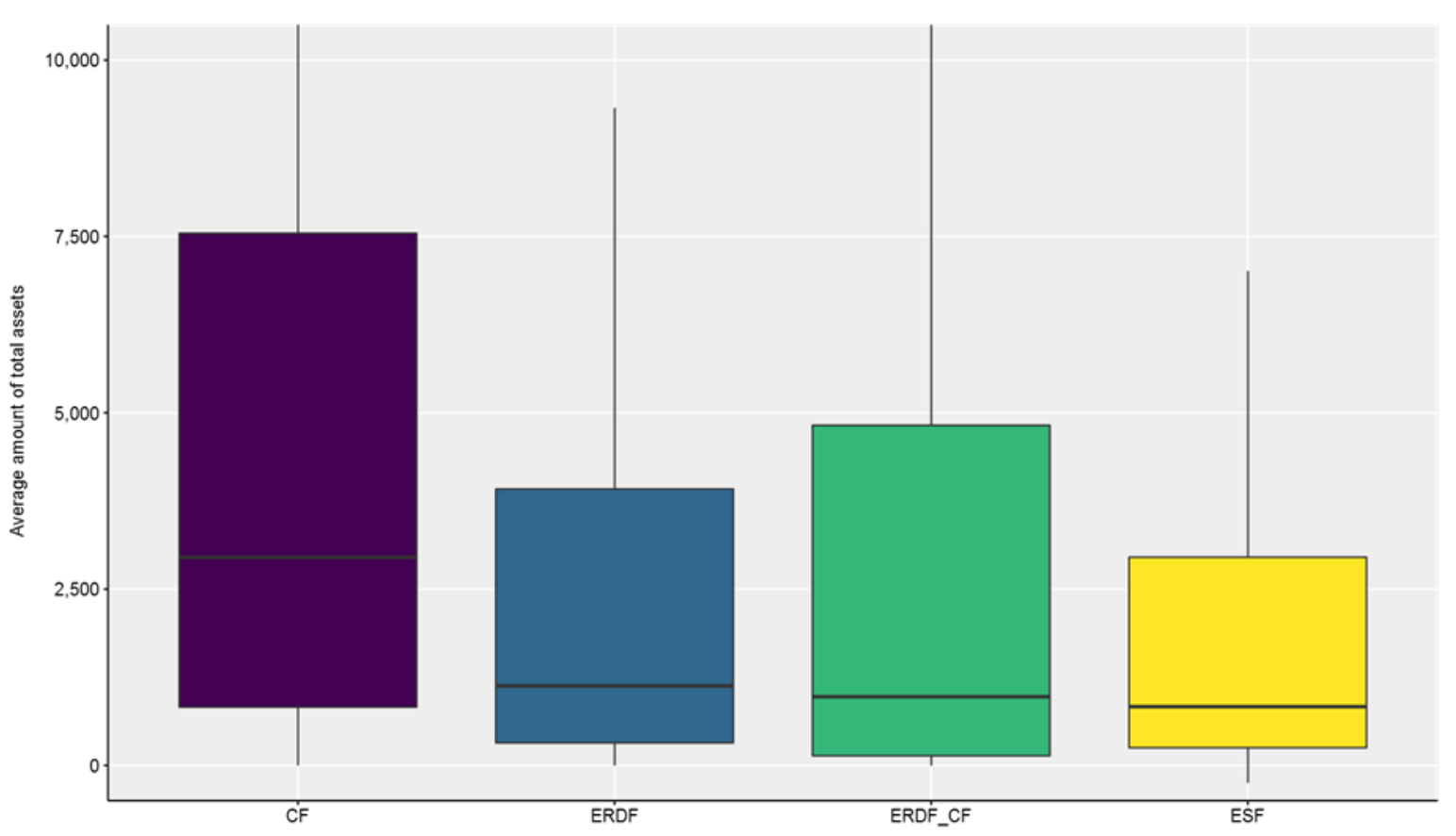

Figure 8. Distribution of firm size by type of fund

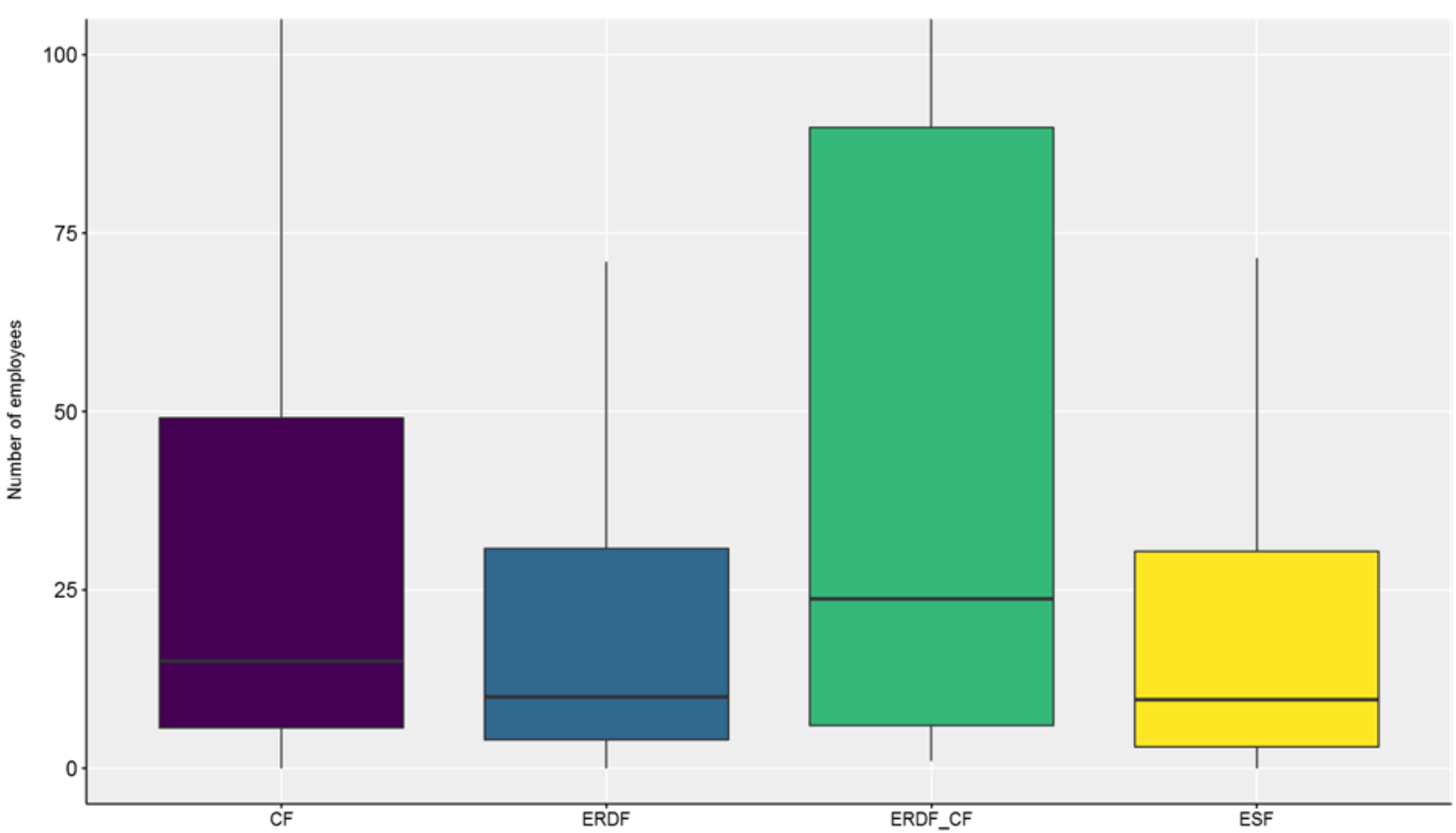


Figure 9. Distribution of capital-labour-ratio by fund

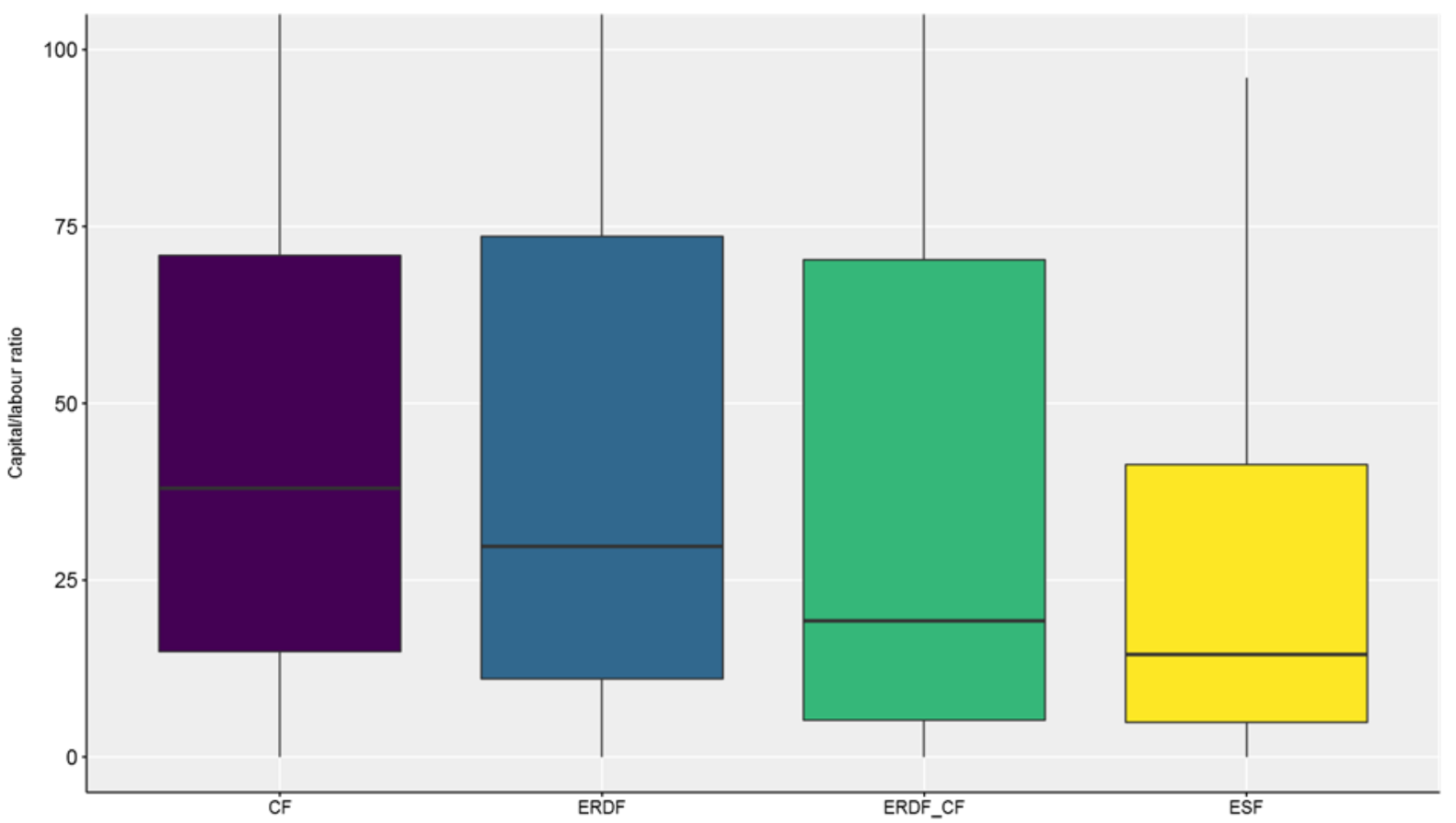

Part of the explanation of this pattern comes from the correlation of funds and industry (Table 6) on the one hand, and funds and themes (Table 7) on the other hand.

\section{BIBLIOGRAPHY}

Andrews, D., Criscuolo, C. \& Gal, P. N., 2015. Frontier firms, technology diffusion and public policy: micro evidence from OECD countries (Vol 2). OECD Publishing, Paris.

Angrist, J. D. \& Pischke, J. S., 2008. Mostly harmless econometrics: An empiricist's companion. s.1.:Princeton University Press.

Bachtler, J., Mendez, C. \& Oraze.H, 2014. From conditionality to Europeanization in Central and Eastern Europe: Administrative performance and capacity in cohesion policy. European Planning Studies, 22(4), pp. 735-757.

Bachtrögler, J., 2016. On the effectiveness of EU structural funds during the Great Recession: Estimates from a heterogeneous local average treatment effects framework. Department of Economics Working Paper Series, 230.

Bachtrögler, J., Fratesi, U. \& Perucca, G., 2017a. The influence of the local context on the implementation and impact of EU Cohesion Policy. Groningen, Paper presented at ERSA Congress 2017. 
Bachtrögler, J., Hammer, C., Reuter, W. H. \& Schwendinger, F., (2017b). Spotlight on the beneficiaries of EU regional funds: A new firm-level dataset. s.1.:WU Vienna University of Economics and Business.

Becker, S. O., Egger, P. H. \& Von Ehrlich, M., 2012. Too much of a good thing? On the growth effects of the EU's regional policy. European Economic Review, 56(4), pp. 648-668.

Becker, S. O., Egger, P. H. \& Von Ehrlich, M., 2013. Absorptive capacity and the growth and investment effects of regional transfers: A regression discontinuity design with heterogeneous treatment effects. American Economic Journal: Economic Policy, 5(4), pp. 29-77.

Becker, S. O., Egger, P. H. \& von Ehrlich, M., 2018. Effects of EU Regional Policy: 1989-2013. Regional Science and Urban Economics, Issue 69, pp. 143-152.

Benkovskis, K., Tkacevs, O. \& Yashiro, N., 2018. Importance of EU regional support programmes for firm performance, s.l.: Latvijas Banka, Working Paper 1/2018.

Bergström, F., 2000. Capital Subsidies and the Performance of Firms. Small Business Economics, 14(3), pp. 183-193.

Berlingieri, G., Blanchenay, P., Calligaris, S. \& Criscuolo, C., 2017. The Multiprod project: A comprehensive overview, OECD Science, Technology and Industry Working Papers, 2017/04, OECD Publishing, Paris.

Bernini, C. \& Pellegrini, G., 2011. How are growth and productivity in private firms affected by public subsidy? Evidence from a regional policy. Regional Science and Urban Economics, 41(3), pp. $253-$ 265 .

Bondonio, D. \& Greenbaum, R. T., 2006. Do business investments incentives promote employment in declining areas? Evidence from EU objective-2 regions. European Urban and Regional Studies, 13(3), pp. 225-244.

Bondonio, D. \& Greenbaum, R. T., 2014. Revitalizing regional economies through enterprise support policies: an impact evaluation of multiple instruments. European Urban and Regional Studies, 21(1), pp. 79-103.

Breidenbach, P., Mitze, T. \& Schmidt, C. M., 2016. EU Structural Funds and Regional Income Convergence-A sobering experience. CEPR Discussion Paper, Issue No. 11210.

Camagni, R. and Capello, R. (2015), 'Rationale and design of EU cohesion policies in a period of crisis', Regional Science Policy \& Practice 7(1).

Capellen, A., Castellacci, F., Fagerberg, J. \& Verspagen, B., 2003. The impact of Eu regional support on growth and convergence in the European Union. JCMS: Journal of Common Market Studies, 41(4), pp. 621-644.

Dall'Erba, S. \& Fang, F., 2017. Meta-analysis of the impact of European Union Structural Funds on regional growth. Regional Studies 51(6), 822-832.

Dall'Erba, S. \& Le Gallo, J., 2008. Regional convergence and the impact of European structural funds over 1989-1999: A spatial econometric analysis. Papers in Regional Science, 87(2), pp. 219-244. 
European Commssion, 2006. Commission Regulation (EC) No 1828/2006 of 8 December 2006, setting out rules for the implementation of Council Regulation (EC) No 1083/2006 laying down general provisions on the ERDF, the ESF and the CF and. s.1.:s.n.

European Council, 2006. Council Regulation (EC) No 1083/2006 of 11 July 2006, laying down general provisions on the European Regional Development Fund, the European Social Fund and the Cohesion Fund and repealing Regulation (EC) No 1260/1999. s.l.:s.n.

Fattorini, L., Ghodsi, M. \& Rungi, A., 2018. Cohesion Policy Meets Heterogenous Firms, Vienna: The Vienna Institute for International Economic Studies.

Ferrara, A. R. et al., 2016. Assessing the impacts of Cohesion Policy on EU regions: A non-parametric analysis on interventions promoting research andinnovation and transport accessibility. Papers in Regional Science.

Gagliardi, L. \& Percoco, M., 2017. The impact of european cohesion policy in urban and rural regions. Regional Studies, 51(6), pp. 857-868.

Gal, P. N., 2013. Measuring Total Factor Productivity at the Firm Level using OECD-ORBIS, Paris: OECD Economics Department Working Paper, No. 1049.

Greene, W.H., 2012. Econometric analysis (International edition). $7^{\text {th }}$ edition.

Hagen, T. \& Mohl, P., 2009. Econometric evaluation of EU cohesion policy: A survey. ZWE Discussion Paper No. 09-052.

Hartsenko, J. \& Sauga, A., 2012. Does financial support from the EU structural funds has an impact on the firms' performance: evidence from Estonia. s.l., Proceedings of 30th International Conference Mathematical Methods in Economics.

Kalemli, S. et al., 2015. How to construct nationally representative firm level data from the ORBIS global database. National Bureau of Economic Research.

Maroshegyi, C. \& Nagy, S. G., 2010. Maroshegyi, Christopher, and Sándor Gyula Nagy. "Out of credit: Evaluating the impact of the EU structural funds on Hungarian small business growth and access to finance. Köz-gazdaság, 5(3), pp. 113-127.

Maynou, L., Saez, M., Kyriacou, A. \& Bacaria, J., 2016. The impact of structural and cohesion funds on eurozone convergence, 1990-2010. Regional Studies, 50(7), pp. 1127-1139.

OECD, 2017. The Geography of Firm Dynamics: Measuring Business Demography for Regional Development, Paris: OECD Publishing.

Percoco, M., 2013. Strategies of regional development in European regions: Are they efficient?. Cambridge Journal of Regions, Economy and Society, pp. 303-318.

Pienkowski, J. \& Berkowitz, P., 2016. Econometric assessments of Cohesion Policy growth effects. In Bachtler et al. (Eds.), EU Cohesion Policy (Open Access) (pp. 55-68). Taylor \& Francis Group

Pinto Ribeiro, S., Menghinello, S. \& De Backer, K., 2010. The OECD ORBIS Database: Responding to the Need for Firm-Level Micro-Data in the OECD, Paris: OECD Publishing. 
Rodríguez-Pose, A. \& Fratesi, U., 2004. Between development and social policies: The impact of European structural funds in Objective 1 regions. Regional Studies, 38(1), pp. 97-113.

Rodríguez-Pose, A. \& Fratesi, U., 2013. Do institutions matter for regional development?. Regional Studies, Volume 7, pp. 1034-1047. 